\title{
Inverse modeling of the Chernobyl source term using atmospheric concentration and deposition measurements
}

\author{
Nikolaos Evangeliou ${ }^{1}$, Thomas Hamburger ${ }^{1, a}$, Anne Cozic ${ }^{2}$, Yves Balkanski ${ }^{2}$, and Andreas Stohl ${ }^{1}$ \\ ${ }^{1}$ NILU - Norwegian Institute for Air Research, Department of Atmospheric and Climate Research (ATMOS), \\ Kjeller, Norway \\ ${ }^{2}$ CEA-UVSQ-CNRS UMR 8212, Laboratoire des Sciences du Climat et de l'Environnement (LSCE), \\ Institut Pierre et Simon Laplace, L'Orme des Merisiers, 91191 Gif-sur-Yvette CEDEX, France \\ anow at: BfS - Bundesamt für Strahlenschutz, Section SW 2.2, Decision Support Systems, 85764 Oberschleißheim, Germany \\ Correspondence to: Nikolaos Evangeliou (nikolaos.evangeliou@nilu.no)
}

Received: 8 April 2017 - Discussion started: 18 April 2017

Revised: 16 June 2017 - Accepted: 22 June 2017 - Published: 20 July 2017

\begin{abstract}
This paper describes the results of an inverse modeling study for the determination of the source term of the radionuclides ${ }^{134} \mathrm{Cs},{ }^{137} \mathrm{Cs}$ and ${ }^{131}$ I released after the Chernobyl accident. The accident occurred on 26 April 1986 in the Former Soviet Union and released about $10^{19} \mathrm{~Bq}$ of radioactive materials that were transported as far away as the USA and Japan. Thereafter, several attempts to assess the magnitude of the emissions were made that were based on the knowledge of the core inventory and the levels of the spent fuel. More recently, when modeling tools were further developed, inverse modeling techniques were applied to the Chernobyl case for source term quantification. However, because radioactivity is a sensitive topic for the public and attracts a lot of attention, high-quality measurements, which are essential for inverse modeling, were not made available except for a few sparse activity concentration measurements far from the source and far from the main direction of the radioactive fallout.

For the first time, we apply Bayesian inversion of the Chernobyl source term using not only activity concentrations but also deposition measurements from the most recent public data set. These observations refer to a data rescue attempt that started more than 10 years ago, with a final goal to provide available measurements to anyone interested. In regards to our inverse modeling results, emissions of ${ }^{134} \mathrm{Cs}$ were estimated to be $80 \mathrm{PBq}$ or $30-50 \%$ higher than what was previously published. From the released amount of ${ }^{134} \mathrm{Cs}$, about $70 \mathrm{PBq}$ were deposited all over Europe. Similar to ${ }^{134} \mathrm{Cs}$, emissions of ${ }^{137} \mathrm{Cs}$ were estimated as $86 \mathrm{PBq}$, on the same
\end{abstract}

order as previously reported results. Finally, ${ }^{131} \mathrm{I}$ emissions of $1365 \mathrm{PBq}$ were found, which are about $10 \%$ less than the prior total releases.

The inversion pushes the injection heights of the three radionuclides to higher altitudes (up to about $3 \mathrm{~km}$ ) than previously assumed $(\approx 2.2 \mathrm{~km})$ in order to better match both concentration and deposition observations over Europe. The results of the present inversion were confirmed using an independent Eulerian model, for which deposition patterns were also improved when using the estimated posterior releases. Although the independent model tends to underestimate deposition in countries that are not in the main direction of the plume, it reproduces country levels of deposition very efficiently. The results were also tested for robustness against different setups of the inversion through sensitivity runs. The source term data from this study are publicly available.

\section{Introduction}

About 30 years ago, on 26 April 1986, the worst nuclear accident in human history took place in the nuclear power plant (NPP) complex "V. I. Lenin" of the Former Soviet Union (FSU), near the city of Pripyat and in proximity to the administrative border of Ukraine with Belarus. The disaster began during a systems test at reactor four. There was a sudden and unexpected power surge and when an emergency shutdown was attempted, a much larger spike in power output occurred, which led to a reactor vessel rupture and a series of steam 
explosions. These events exposed the graphite moderator of the reactor to air, causing it to ignite (Burakov et al., 1996; Medvedev, 1990). The resulting fire sent a plume of highly radioactive fallout into the atmosphere, which dispersed over an extensive geographical area. Around $10 \mathrm{EBq}\left(10^{19} \mathrm{~Bq}\right)$ of fission products were released, of which the largest fraction were noble gases (De Cort et al., 1998). The most severe contamination occurred in FSU countries (Ukraine, Belarus and Russia) (Izrael et al., 1990, 1996). From 1986 to 2000, 350000 to 400000 people were evacuated and resettled from the most severely contaminated areas of Belarus, Russia and Ukraine (Cardis et al., 1996; Fairlie and Sumner, 2006).

Shortly after the accident became known to the public, concerns were put forward about the extent of radioactive pollution and the exposure to radiation of the European population. Many countries in Europe (e.g., Hamilton et al., 1986; Kauppinen et al., 1986) and outside Europe, such as the USA (e.g., Bondiett and Brantley, 1986), Taiwan (e.g., Chung and Lo, 1986) and Japan (e.g., Aoyama et al., 1987; Nishizaw et al., 1986), started reporting unusually high levels of radioactivity in environmental media. After the accident, the REM (Radioactivity Environmental Monitoring) programme was established with the aim to improve procedures for the collection, evaluation and harmonization of environmental radioactivity concentrations and the modeling of the migration of radioactivity in the environment for routine and emergency conditions (JRC, 2016). In parallel, several research groups worldwide started independently reporting observations of surface atmospheric concentrations and deposition taken for research purposes. A direct outcome of the REM project was the "Atlas of caesium deposition on Europe after the Chernobyl accident" (hereafter Atlas) based on 500000 measurements all over Europe, $60 \%$ of which had been collected in the FSU.

\section{Earlier estimates of the source term and purpose of the paper}

Early studies published just after the accident (e.g., IAEA, 1992; SCUAE, 1986) gave estimates of the total emitted activity and made first assessments of the temporal release profiles, although not all of them agreed on the total emitted amount or the vertical position of the releases, i.e., the heights to which radioactive material was vented by the explosions and fires. However, it was clearly emphasized that the releases may have reached the free troposphere due to the pronounced steam explosions and the following thermal explosion. First estimates were published in a USSR report (SCUAE, 1986), estimating that $1.76 \mathrm{EBq}$ of ${ }^{131} \mathrm{I}, 85 \mathrm{PBq}$ of ${ }^{137} \mathrm{Cs}$ and $54 \mathrm{PBq}$ of ${ }^{134} \mathrm{Cs}$ were released, Abagyan et al. (1986) reported releases of $38.7 \mathrm{PBq}$ of ${ }^{137} \mathrm{Cs}$ and $482 \mathrm{PBq}$ of ${ }^{131} \mathrm{I}$. Persson et al. (1987), as well as Albergel et al. (1988), reported a similar source term as in SCUAE (1986) but with different injection altitudes. Later on, Devell et al. (1995) and De Cort et al. (1998) published more refined estimations of the release history. Official results on the source term were published almost 10 years after the accident in the 1995 OECD report (Waight et al., 1995), which estimated total releases for ${ }^{131} \mathrm{I},{ }^{137} \mathrm{Cs}$ and ${ }^{134} \mathrm{Cs}$ that were the same as in SCUAE (1986). More recently, Brandt et al. (2002) used these official emissions estimates and found excellent agreement between modeling results and observations for surface concentrations. Finally, Davoine and Bocquet (2007) reported releases of $1.82 \mathrm{EBq}$ of ${ }^{131} \mathrm{I}, 136 \mathrm{PBq}$ of ${ }^{137} \mathrm{Cs}$ and $35 \mathrm{PBq}$ of ${ }^{134} \mathrm{Cs}$, respectively.

The bulk of the releases lasted for about 10 days, while later releases were several orders of magnitude lower (De Cort et al., 1998). The first 3 days correspond to the initial explosions (steam and thermal explosions) characterized by ejections of fuel fragments. During the next 4 days weaker releases occurred due to the fire extinguishing attempts of the firefighters. During the last 3 days the emissions rose up again due to the fuel fire and the core meltdown. The altitude at which emissions were injected into the atmosphere was even more difficult to estimate due to the numerous parameters that have to be taken into consideration (mechanical factors characterizing the explosions, generated heat, local meteorological factors, local scavenging conditions, boundary layer diurnal cycles, etc.). Albergel et al. (1988) and Gudiksen et al. (1989) reported that the first release must have reached $2000 \mathrm{~m}$ or more. A similar profile of the Chernobyl emissions was proposed by Lange et al. (1988) and Hass et al. (1990).

The goal of this paper is to reconstruct and assess the source term based on inverse modeling techniques. We focus on the temporal variations and the altitude of the releases. Although reportedly 500000 deposition measurements were used to create the Atlas map, only 5000 deposition measurements were made available to the public in the REM database, and very few of these data referred to the FSU countries, where the highest contamination occurred. Therefore, inverse modeling studies for the quantification of the source term of Chernobyl were mainly based on atmospheric concentrations only (e.g., Davoine and Bocquet, 2007). For the first time, we perform inverse modeling calculations using an extended data set of deposition observations for ${ }^{134} \mathrm{Cs}$, ${ }^{137} \mathrm{Cs}$ and ${ }^{131} \mathrm{I}$ (Evangeliou et al., 2016) together with surface atmospheric activity concentrations. The data set that we used consists of 3000 observations for ${ }^{134} \mathrm{Cs}$ and 11000 observations for ${ }^{137} \mathrm{Cs}, 60 \%$ of which were made in the FSU countries. The data originate from the public REM database of the Joint Research Centre, enriched with measurements from Ukraine, Belarus and Russia and a few other countries. All of these data were used for creating the original Atlas map, but they were not included in the public REM database and were thus inaccessible. These data have been recovered in a recent data rescue effort (see Evangeliou et al., 2016). All simulations regarding the inversion were performed us- 
ing FLEXPART version 10 combined with a Bayesian inversion algorithm (see next section).

\section{Methodology}

\subsection{Experimental setup}

We used the Lagrangian particle dispersion model FLEXPART version 10 (Stohl et al., 1998, 2005) to simulate transport and deposition of radionuclides. This model was originally developed for calculating the dispersion of radioactive material from nuclear emergencies, but since then it has been used for many other applications as well. Nuclear emergency applications include simulations of the transport of radioactive materials from NPPs and other facilities (Andreev et al., 1998; Wotawa et al., 2010) or from nuclear weapon tests (Becker et al., 2010). The model has a detailed description of particle dispersion in the boundary layer and a convection scheme to describe particle transport in clouds (Forster et al., 2007).

Due to the fact that the Chernobyl accident took place 30 years ago, when meteorological models were much simpler than nowadays, the quality of the operational meteorological analyses at that time was low compared to current operational data. For this reason, to drive FLEXPART we used ERA-40 (Uppala et al., 2005), which is a European Centre for Medium-range Weather Forecast (ECMWF) reanalysis (using three-dimensional variational data assimilation, 3D-Var) of the global atmosphere and surface conditions for 45 years (1957-2002) at a $125 \mathrm{~km}$ resolution. Furthermore, we used ERA-Interim (Dee et al., 2011), which is a global atmospheric reanalysis from 1979, continuously updated in real time. This system includes a four-dimensional variational analysis (4D-Var) with a $12 \mathrm{~h}$ analysis window. The spatial resolution of the data set is approximately $80 \mathrm{~km}$ on 60 vertical levels from the surface up to $0.1 \mathrm{hPa}$.

We discretized the emissions from Chernobyl into 576 distinct pulses ( 6 vertical layers $\times 963 \mathrm{~h}$ intervals between 00:00 UTC on 26 April and 00:00 UTC on 8 May) and ran the dispersion model forward in time for each one of the 576 emission array elements. Each one of these simulations quantified the sensitivity of downwind atmospheric activity concentrations and depositions to the emissions in a single time-height emission array element. 300000 particles per release were used for each simulation, giving a total of about 172.8 million particles. To assess the impact of a given release scenario, we also used the model in the same setup but using time- and altitude-varying emissions instead of pulse emissions. Three aerosol tracers (for ${ }^{134} \mathrm{Cs},{ }^{137} \mathrm{Cs}$ and ${ }^{131} \mathrm{I}$ ) subject to wet and dry deposition were used. While cesium is almost entirely attached onto particle surfaces, iodine can be present in the atmosphere as molecular $\mathrm{I}_{2}$, as organic iodide or as iodide salts. While $I_{2}$ is a gas, iodide salts are aerosols. In which form iodine is released to the environment from a nuclear facility depends on its operating conditions (Simondi-Teisseire et al., 2013). Furthermore, iodine chemistry in the atmosphere is complex and can involve, for instance, chemical transformation of the different compounds and particle formation (Saiz-Lopez et al., 2012). Without further information, it is impossible to accurately model the atmospheric processes related to the radioiodine release from Chernobyl. Therefore, we chose a simple approach for our modeling, namely assuming that all released ${ }^{131} \mathrm{I}$ was in particulate form. Radioactive decay was not included in the model simulations, since all radionuclide observations and also the a priori emission data were decay corrected to the time of the accident for the purpose of the inverse modeling.

The simulations accounted for wet and dry deposition, assuming a particle density of $2500 \mathrm{~kg} \mathrm{~m}^{-3}$ and four different fractions of each radionuclide with aerodynamic mean diameters of $0.4,1.2,1.8$ and $5.0 \mu \mathrm{m}$ and logarithmic standard deviations of $1.35,1.25,1.20$ and 1.35 , respectively. The four different size bins $(0.4,1.2,1.8$ and $5.0 \mu \mathrm{m})$ received 15,30 , 40 and $15 \%$ of the emitted mass following Malá et al. (2013). The wet deposition scheme considers below-cloud and incloud scavenging separately based on cloud liquid water and cloud ice content, precipitation rate and cloud depth from ECMWF, as described in Grythe et al. (2017).

\subsection{Inverse modeling}

We used the inversion algorithm previously used to calculate the source term of ${ }^{133} \mathrm{Xe}$ and ${ }^{137} \mathrm{Cs}$ in the recent accident in Fukushima NPP (Japan) in 2011 (Stohl et al., 2012), the emissions of greenhouse gases (Stohl et al., 2009) and volcanic sulfur dioxide and ash emissions (Kristiansen et al., 2010; Stohl et al., 2011). The algorithm is based on original work by Seibert (2000), incorporates different types of observation data and can be based on forward or backward calculations with FLEXPART. A full description of the algorithm has been given elsewhere (Seibert et al., 2011). The inversion setup is almost identical to that described by Stohl et al. (2012) for determining the Fukushima emissions as a function of time and altitude.

We determine radionuclide emissions as a function of time for 96 3-hourly intervals between 00:00 UTC on 26 April and 00:00 UTC on 8 May. While basically all published estimates (e.g., De Cort et al., 1998) suggest that the emissions after 5 May were about 6 orders of magnitude lower than before, we also included 6 and 7 May in our inversion to verify this. The inversion was also done for six vertical levels $(0$ $0.5,0.5-1.0,1.0-1.5,1.5-2.0,2.0-2.5,2.5-3.0 \mathrm{~km}$ ), yielding a total of $n=576$ unknowns (i.e., emission values) denoted as vector $x$. For each one of the $n$ unknowns, a unit amount of radionuclide was emitted in FLEXPART and the model results (surface concentrations or deposition values) were matched (i.e., ensuring spatiotemporal co-location) with $m$ radionuclide observations put into a vector $\boldsymbol{y}_{0}$. Modeled val- 
ues $\boldsymbol{y}$ corresponding to the observations can be calculated as

$\boldsymbol{y}=\mathbf{M} \cdot \boldsymbol{x}$,

where $\mathbf{M}$ is the $m \times n$ matrix of source-receptor relationships calculated with FLEXPART. As the problem is illconditioned, with the measurement data not giving a strong constraint on all elements of the source vector, additional a priori information on the emissions is necessary to stabilize the solution. Including the a priori (prior) source vector $\boldsymbol{x}^{\mathrm{a}}$, Eq. (1) becomes

$\mathbf{M} \times\left(\boldsymbol{x}-\boldsymbol{x}^{\mathrm{a}}\right) \approx \boldsymbol{y}^{\mathrm{o}}-\mathbf{M} \times \boldsymbol{x}^{\mathrm{a}}$,

which as an abbreviation is

$\mathbf{M} \cdot \overline{\boldsymbol{x}} \approx \overline{\boldsymbol{y}}$.

Considering standard deviations of the errors while assuming the errors to be uncorrelated, the cost function is

$$
\begin{aligned}
J= & (\mathbf{M} \cdot \overline{\boldsymbol{x}}-\overline{\boldsymbol{y}})^{\mathrm{T}} \cdot \operatorname{diag}\left(\boldsymbol{\sigma}_{\mathrm{o}}^{-2}\right) \cdot(\mathbf{M} \cdot \overline{\boldsymbol{x}}-\overline{\boldsymbol{y}}) \\
& +\overline{\boldsymbol{x}}^{\mathrm{T}} \cdot \operatorname{diag}\left(\boldsymbol{\sigma}_{x}^{-2}\right) \cdot \overline{\boldsymbol{x}}+(\mathbf{D} \overline{\boldsymbol{x}})^{\mathrm{T}} \cdot \operatorname{diag}(\epsilon) \cdot \mathbf{D} \overline{\boldsymbol{x}} .
\end{aligned}
$$

The first term on the right-hand side of Eq. (4) measures the model-observation misfit, the second term is the deviation from the a priori values, and the third term measures the deviation of the temporal emission profile from smoothness. Vector $\sigma_{\mathrm{o}}$ is the standard error of the observations and vector $\sigma_{x}$ is the standard error of the a priori values. The operator $\operatorname{diag}(a)$ yields a diagonal matrix with the elements of $a$ in the diagonal. $\mathbf{D}$ is a matrix with elements equal to -2 or 1 , giving a discrete representation of the second derivative, and $\epsilon$ is a regularization parameter determining the weight of the smoothness constraint compared to the other two terms.

Equation (4) implies normally distributed, uncorrelated errors, a condition that is not generally fulfilled. To quantify the model errors, we used an ensemble of FLEXPART simulations using two meteorological data sets (ERA-40 and ERAInterim) for all three radionuclides of interest. The inversion algorithm reads the source-receptor relationships calculated in FLEXPART simultaneously in order to evaluate a range of prior modeled concentrations and deposition densities. Observation errors may be correlated with neighboring values, and deviations from the prior sources are likely to be asymmetric, with overestimation being more likely than underestimation as zero is a natural bound. The justification for using this approach is that the problem becomes much easier to solve, detailed error statistics are unknown anyway, and experience shows that reasonable results can be obtained. Negative emission values can occur in this setup but were removed in an iterative procedure by binding them more strongly to the positive a priori values (i.e., by reducing the uncertainty of these emission elements).

For ${ }^{134} \mathrm{Cs}$ and ${ }^{137} \mathrm{Cs}$, we have used measurements of both atmospheric activity concentrations and deposition to constrain the source term (see Sect. 3.4) despite the additional uncertainties contained in the modeled deposition values, primarily related to errors in precipitation information and the scavenging formulation (Gudiksen et al., 1989). However, if the measurements are sparse, all available data should be used, even if not all data can be modeled with the same accuracy. The limitations on performing an inversion using deposited activity measurements were highlighted by Gudiksen et al. (1989). These limitations are associated with the uncertainties of precipitation in the meteorological data sets and of the scavenging schemes used in models, as well as with the unknown mass of ${ }^{137} \mathrm{Cs}$ deposited over Europe as a result of nuclear weapon tests in the past. However, 30 years after the accident, the mass of ${ }^{137} \mathrm{Cs}$ attributed to the nuclear weapon tests has been well documented for Europe: it has been reported to be up to $3.5 \mathrm{kBq} \mathrm{m}^{-2}$ (De Cort et al., 1998) and has been removed from the observation data sets. In addition, meteorological data have been improved tremendously with the generation of reanalysis fields (e.g., from ECMWF; Dee et al., 2011; Uppala et al., 2005), which are more accurate and have better spatial resolution compared to operational data available at the time of the accident. The latter, in conjunction with the more sophisticated and realistic scavenging schemes used currently in models (e.g., Grythe et al., 2017), supports more accurate simulations of the atmospheric dispersion of radioactive material.

In the present case, model and measurement error were combined into the observation error $\sigma \mathrm{o}=\sqrt{\sigma_{\text {meas }}^{2}+\sigma_{\text {mod }}^{2}}$, where $\sigma_{\text {meas }}$ is the measurement error and $\sigma_{\text {mod }}$ the model error. While the inversion method formally propagates stochastic errors in the input data into an a posteriori emission error, the overall error is determined also by partly systematic other errors, which are difficult to quantify. One possible such error source is systematic errors in simulating the deposition process, leading to biases in atmospheric aerosol lifetime. In that respect, it is beneficial to use both atmospheric concentration and deposition measurements, as errors in modeling the deposition process will affect atmospheric concentrations and deposition values (at least partly) in the opposite way (i.e., overestimating deposition will lead to underestimates of atmospheric concentrations). Thus, combining these two types of data will partly lead to error compensation in inverse modeling.

\subsection{Prior emissions of ${ }^{134} \mathrm{Cs},{ }^{137} \mathrm{Cs}$ and ${ }^{131} \mathrm{I}$}

Figure 1 shows the time profiles of the released quantities of ${ }^{131} \mathrm{I},{ }^{134} \mathrm{Cs}$ and ${ }^{137} \mathrm{Cs}$ published in different studies of the Chernobyl accident (Abagyan et al., 1986; Brandt et al., 2002; Izrael et al., 1990; Persson et al., 1987; Talerko, $2005 \mathrm{a}, \mathrm{b})$. These estimates were used as an ensemble of different alternative a priori source vectors in our inversion. It should be noted that only source terms published with sufficient temporal and emission height information were considered. In Brandt et al. (2002), total released amounts of 
Previously published emission estimates

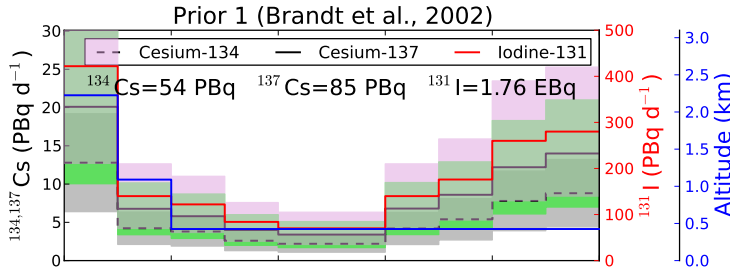

Prior 3 (Persson et al., 1987)

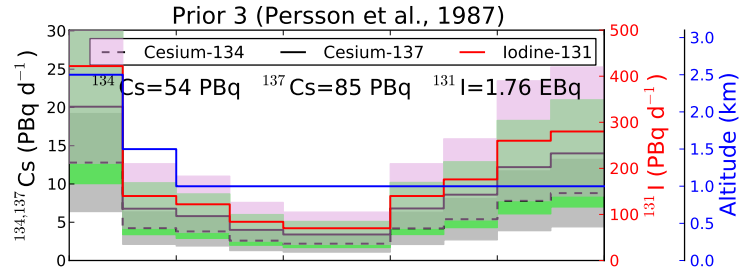

Prior 5 (Abagyan et al., 1986)

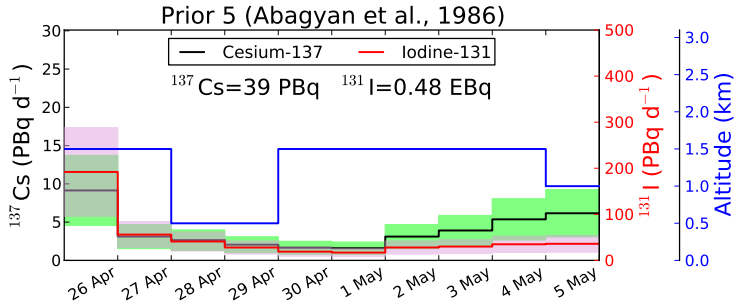

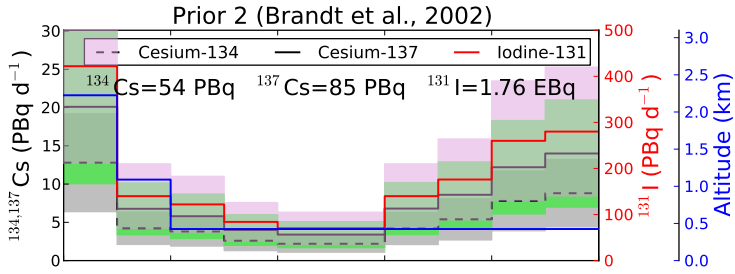

Prior 4 (Izrael et al., 1990)

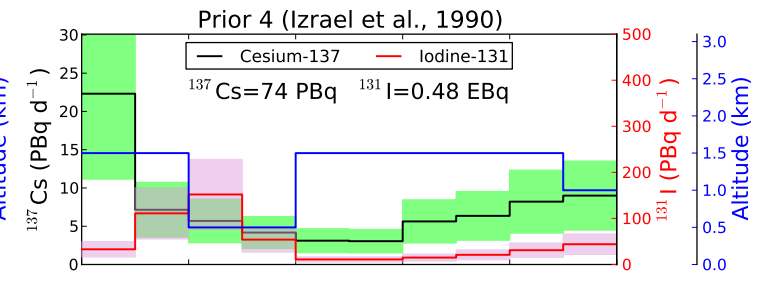

Prior 6 (Talerko, 2005)

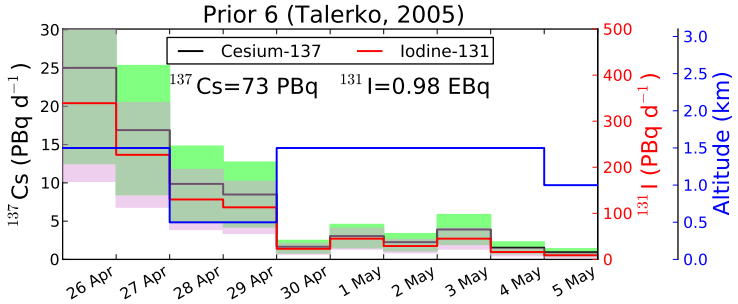

Figure 1. Six different profiles of source releases for ${ }^{134} \mathrm{Cs}$ (black dashed line), ${ }^{137} \mathrm{Cs}$ (black line) and ${ }^{131}$ I (red line), published after the Chernobyl accident. These emissions were used to calculate the a priori (prior) source information and the relative uncertainty of the inversion. Blue line indicates the maximum altitude of the emissions.

${ }^{134} \mathrm{Cs},{ }^{137} \mathrm{Cs}$ and ${ }^{131} \mathrm{I}$ were $54,85 \mathrm{PBq}$ and $1.76 \mathrm{EBq}$, respectively, and the highest altitude of the release was $2.2 \mathrm{~km}$ on 26 April, gradually decreasing during the following days. For this first release (Prior 1, Fig. 1), we assumed that each particle was injected exactly at each specific altitude without giving any range in the altitude. For the second one (Prior 2), the same mass as in Brandt et al. (2002) was released, but it was equally distributed within the corresponding height layer used for the inverse modeling (Fig. 1). For instance, instead of injecting the released mass of ${ }^{137} \mathrm{Cs}$ at exactly $2.2 \mathrm{~km}$, we injected it between 2.0 and $2.5 \mathrm{~km}$.

The next source profile (Prior 3) was from Persson et al. (1987), who reported the same release amount but reported a release height that reached $2.5 \mathrm{~km}$ during the first day (compared to $2.2 \mathrm{~km}$ in Brandt et al., 2002) and $1.0 \mathrm{~km}$ in the following release days (compared to $0.4 \mathrm{~km}$ in Brandt et al., 2002). Izrael et al. (1990) reported emission amounts for ${ }^{137} \mathrm{Cs}$ and ${ }^{131}$ I only and found that 73 and $483 \mathrm{PBq}$ were released, respectively, at heights of up to $1.5 \mathrm{~km}$ during the first 2 days, at $0.5 \mathrm{~km}$ during the third and fourth day, and again up to $1500 \mathrm{~m}$ in the following (Prior 4). In one of the first assessments of the source term (Prior 5), Abagyan et al. (1986) reported lower releases than the other studies for ${ }^{137} \mathrm{Cs}$ (39 PBq), while ${ }^{131} \mathrm{I}$ releases (482 PBq) were more comparable. The vertical profile of the release was the same as in Izrael et al. (1990). Finally, the last release (Prior 6) was adopted from Talerko (2005a, b), who reported that $73 \mathrm{PBq}$ of ${ }^{137} \mathrm{Cs}$ and $976 \mathrm{PBq}$ of ${ }^{131} \mathrm{I}$ were released at the same heights, as Abagyan et al. (1986) and Izrael et al. (1990) had suggested before.

To define our a priori emissions (vector $\boldsymbol{x}^{\mathrm{a}}$ ) and their uncertainties (vector $\sigma_{x}$ in Eq. 4), we have used the aforementioned published releases as an ensemble to calculate the daily average emissions of ${ }^{134} \mathrm{Cs},{ }^{137} \mathrm{Cs}$ and ${ }^{131} \mathrm{I}$ and the respective standard deviations (Fig. 2). Accordingly, $54 \pm$ $9 \mathrm{PBq}$ of ${ }^{134} \mathrm{Cs}, 74 \pm 15 \mathrm{PBq}$ of ${ }^{137} \mathrm{Cs}$ and $1510 \pm 395 \mathrm{PBq}$ of ${ }^{131}$ I were emitted in total during the 10-day period of the releases. As expected, the most uncertain releases occurred during the 2 first days of the accident, when a dual explosion took place, and during the last 2 days, when the fuel was ignited. These events were accounted for quite differently in the previously published estimates (see Fig. 1).

All previous studies suggested that emissions ended abruptly on 5 May, with later emissions being lower by 6 orders of magnitude (De Cort et al., 1998). For our inversion, we extended the potential emission period by 2 days, to identify potential late emissions. For this, we used prior emissions of $5 \mathrm{TBq}$ day ${ }^{-1}$ for ${ }^{134} \mathrm{Cs}, 10 \mathrm{TBq}$ day $^{-1}$ for ${ }^{137} \mathrm{Cs}$ and $100 \mathrm{TBq}$ day $^{-1}$ for ${ }^{131} \mathrm{I}$ on 6 and 7 May (i.e., about 3 orders of magnitude smaller than on 5 May) associated with an uncertainty of $0.5,1$ and $10 \mathrm{PBq}$ day $^{-1}$, respectively (see Fig. 2). Uncertainties of the last two daily emissions were left quite high in order to allow inversion to calculate poten- 


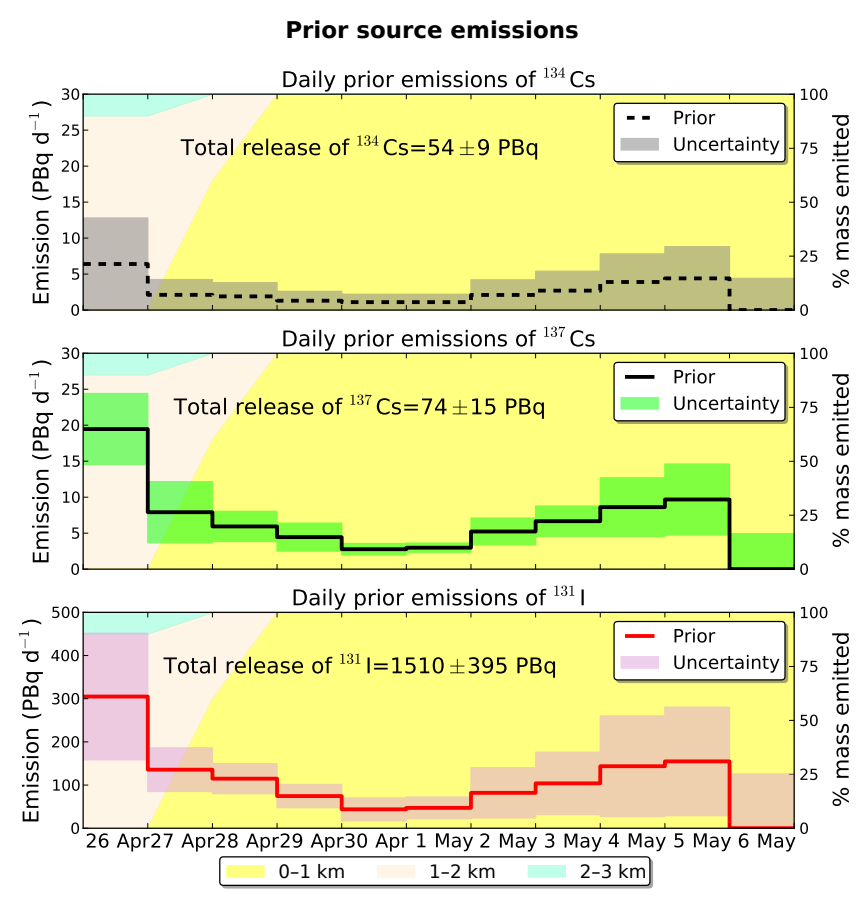

Figure 2. Calculated prior source term and uncertainty for ${ }^{134} \mathrm{Cs}$ (black dashed line), ${ }^{137} \mathrm{Cs}$ (black line) and ${ }^{131} \mathrm{I}$ (red line) from 26 April to 7 May 1986. Note that emissions are plotted only until 6 May for simplicity, as on 6 and 7 May 1986 they were reported to be zero. The prior releases were calculated as the average and standard deviation of the six previously published source terms (prior 1-6) shown in Fig. 1. On the right axis the vertical distribution of the emissions at altitudes $0-1 \mathrm{~km}$ (yellow), 1-2 km (beige) and 2$3 \mathrm{~km}$ (turquoise) is plotted as shaded background colors.

tial posterior releases that are much higher than the reported 6 orders of magnitude lesser levels.

\subsection{Surface activity concentration and deposition observations}

Measurements of surface activity concentrations and deposition densities from all over Europe were adopted from Evangeliou et al. (2016). The database consists of surface air activity concentration measurements (in $\mathrm{Bq} \mathrm{m}^{-3}$ ) of ${ }^{134} \mathrm{Cs}$ (1927 observations), ${ }^{137} \mathrm{Cs}$ (1601) and ${ }^{131} \mathrm{I}$ (2041) and deposition density observations (in $\mathrm{kBq} \mathrm{m}^{-2}$ ) of ${ }^{134} \mathrm{Cs}$ (2966) and ${ }^{137}$ Cs (11334) as shown in Fig. 3. Of the 11334 deposition observations for ${ }^{137} \mathrm{Cs}$, 4077 were adopted from the public REM data set, and the remainder were made available from Talerko (2005a, b) and Kashparov et al. (2003). The data of ${ }^{137}$ Cs deposition over the FSU countries were collected using the standardized method adopted previously in the former USSR (Tsaturov et al., 1996). The samples were collected within national framework programmes for the determination of radioactive deposition in settlements; they were included into the database used for the creation of the Atlas map but not in the public REM database. Air concentrations in areas closer to the vicinity of the plant were determined using airborne gamma spectrometers mounted on aircraft or helicopters capable of flying at low altitudes $(25-100 \mathrm{~m})$ during the initial period after the accident. In countries where concentrations were lower, surface air was sucked through filters for a long time (e.g., hours to days depending on the relevant detection limits and the air concentrations) using high-volume samplers. Then, the filters were measured with gamma spectrometry.

As regards to the relative measurement errors (it is combined with model error to give observation error, Sect. 3.2), the experience gathered from Fukushima was used (Stohl et al., 2012). The use of deposition observations in the inversion involves additional uncertainty compared to surface concentrations due to the unknown mass of each long-lived radionuclide that was deposited previously in the area (e.g., from nuclear weapon tests) and due to the uncertainty of precipitation that differs from different meteorological data sets (Gudiksen et al., 1989). For these reasons, the relative measurement errors were chosen to be double $(60 \%)$ for deposition densities compared to the concentration values (30\%). This, together with the often higher model error, gives deposition values less weight in the inversions in order to account for the aforementioned associated uncertainties. Activity concentrations used in the present inversion were selected from areas with coordinates $10-20^{\circ} \mathrm{E}$ and $40-60^{\circ} \mathrm{N}$, excluding measurements from Budapest (Hungary), Göttingen (Germany) and Prague (Czechia). All the measurements outside this domain together with the excluded ones were used for validation. Similar to concentrations, deposition measurements from another domain $\left(10-40^{\circ} \mathrm{E}\right.$ and $\left.40-60^{\circ} \mathrm{N}\right)$ were used in the inversion due to the different density of observations, whereas the rest were used for validation.

\subsection{The Eulerian chemistry transport model (CTM) LMDz-OR-INCA}

In order to assess the improvement of the emissions achieved by the inversion, we used the LMDz-OR-INCA global CTM to simulate prior and posterior emissions of ${ }^{137} \mathrm{Cs}$. The model is totally different from FLEXPART and couples the LMDz (Laboratoire de Météorologie Dynamique) general circulation model (GCM) (Hourdin et al., 2006) and the INCA (INteraction with Chemistry and Aerosols) model (Folberth et al., 2006; Hauglustaine et al., 2004). The atmospheric model was furthermore coupled to the land surface model ORCHIDEE (ORganizing Carbon and Hydrology In Dynamic Ecosystems) dynamical vegetation model (Krinner et al., 2005). In the present configuration, the model consists of 19 hybrid vertical levels extending to the stratosphere, and a horizontal resolution of $2.5^{\circ} \times 1.3^{\circ}$ (144 grid cells in longitude, 142 in latitude). However, the GCM offers the possibility to zoom over specific regions by stretching the grid with the same number of grid boxes. In the present study, a zoom over Europe $\left(10^{\circ} \mathrm{W}-60^{\circ} \mathrm{E}, 20-80^{\circ} \mathrm{N}\right)$ 


\section{Observations used in the inversion}
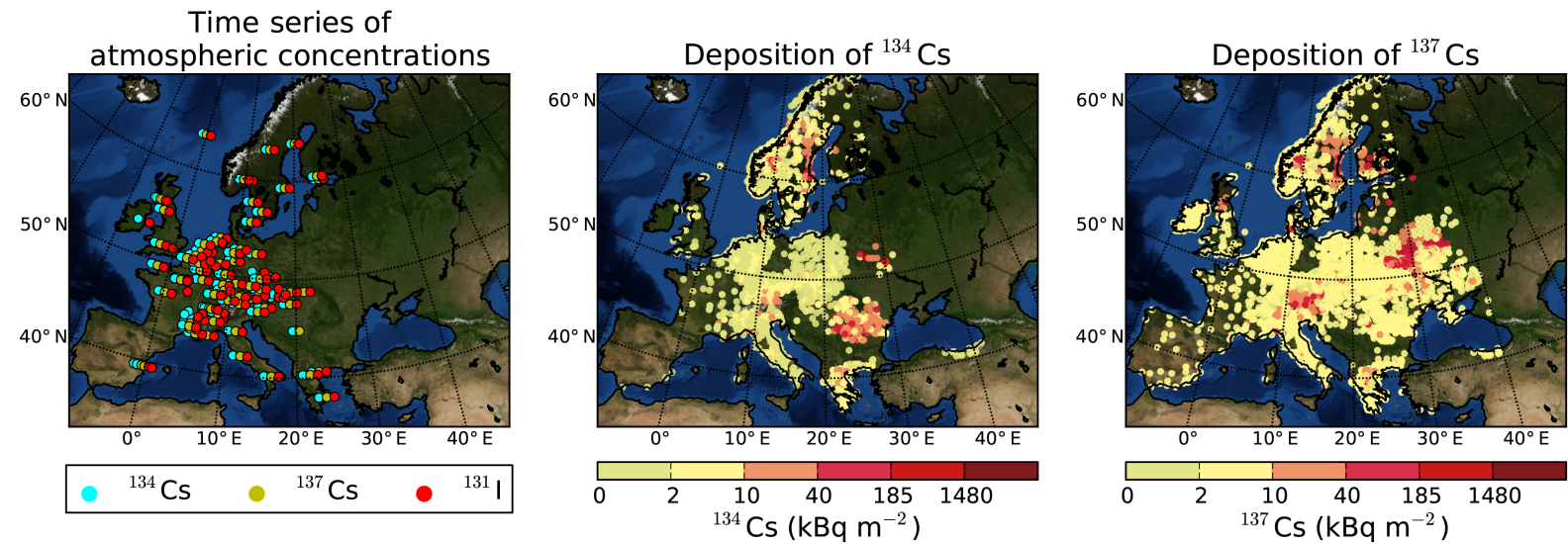

Figure 3. Locations of atmospheric activity concentration measurements of ${ }^{134} \mathrm{Cs},{ }^{137} \mathrm{Cs}$ and ${ }^{131} \mathrm{I}$ and deposition locations and levels of ${ }^{134} \mathrm{Cs}$ and ${ }^{137} \mathrm{Cs}$ over Europe adopted from Evangeliou et al. (2016).

was applied achieving a maximum horizontal resolution of $0.45^{\circ}$ in longitude and $0.51^{\circ}$ in latitude. A more detailed description and an extended evaluation of the GCM can be found in Hourdin et al. (2006). The large-scale advection of tracers was calculated based on a monotonic finite-volume second-order scheme (Hourdin and Armengaud, 1999). Deep convection was parameterized according to the scheme of Emanuel (1991). The turbulent mixing in the planetary boundary layer was based on a local second-order closure formalism.

The model simulates the distribution of natural (e.g., sea salt and dust) and anthropogenic aerosols (sulfates, black carbon, radionuclides). It keeps track of both the number and the mass of aerosols using a modal approach to treat the size distribution, which is described by a superposition of five lognormal modes (Schulz, 2007), each with a fixed spread. The aerosols are treated in three particle modes: sub-micronic (diameter $<1 \mu \mathrm{m}$ ) corresponding to the accumulation mode, micronic (diameter 1-10 $\mu \mathrm{m}$ ) corresponding to coarse particles, and super-micronic or super-coarse particles (diameter $>10 \mu \mathrm{m})$. In the present study, four different particle diameters $(0.4,1.2,1.8$ and $5.0 \mu \mathrm{m})$ were assumed for each of the radionuclides (one in sub-micronic mode and three belonging in the micronic mode) using the prior and posterior emissions, exactly as in the runs with FLEXPART. LMDz-ORINCA accounts for emissions, transport (resolved and subgrid scale) and scavenging (dry deposition and washout) of chemical species and aerosols interactively in the GCM.

Each simulation using LMDz-OR-INCA lasted 9 months (April to December 1986). Using the present experimental setup and considering that the lifetime of ${ }^{137} \mathrm{Cs}$ in the model is around 7 days (Evangeliou et al., 2013), the atmospheric burden of ${ }^{137} \mathrm{Cs}$ in Europe 9 months after the accident is almost zero and everything has been deposited. For this study, the model ran in a nudged mode using 6-hourly ERA-Interim reanalysis data (Dee et al., 2011) with a relaxation time of 10 days (Hourdin and Issartel, 2000).

\section{Results}

\subsection{Selection of the proper meteorological data set}

In order to select the meteorological input data set that is more suitable for simulating the dispersion of the Chernobyl radioactive cloud, we simulated the accident with FLEXPART using the prior source term (Fig. 2) and the two available reanalysis data sets (ERA-40 and ERA-Interim). Figure 4 shows the relative difference $(\%)$ in deposition (i.e., $\left.\left(\mathrm{ERA}_{40}-\mathrm{ERA}_{\text {Interim }}\right) / \mathrm{ERA}_{\text {Interim }}\right)$ over Europe averaged for the studied radionuclides $\left({ }^{134} \mathrm{Cs},{ }^{137} \mathrm{Cs}\right.$ and $\left.{ }^{131} \mathrm{I}\right)$. Moreover, the simulated deposition of ${ }^{134} \mathrm{Cs},{ }^{137} \mathrm{Cs}$ and ${ }^{131}$ I over Europe using both meteorological data sets for the prior emissions can be seen in Fig. S1. The main problem of most model simulations of the accident has been a failure to reproduce concentrations and deposition in remote areas (e.g., Brandt et al., 2002; Evangeliou et al., 2013; Hass et al., 1990; Hatano et al., 1998), where measurements have revealed quite significant contamination (De Cort et al., 1998; Evangeliou et al., 2016). A characteristic example is the Scandinavian countries, Austria and Germany, where measurements have shown deposition densities of ${ }^{134} \mathrm{Cs}$ and ${ }^{137} \mathrm{Cs}$ above $10 \mathrm{kBq} \mathrm{m}^{-2}$ (Fig. 3). In these regions, simulations using the ERA-Interim data failed to deposit such large quantities, whereas using the ERA-40 data set led to a more realistic deposited mass (Fig. S1).

This was confirmed by the root mean square error (RMSE), which is an absolute measure of fit of a variable to observations and is interpreted as the standard deviation of the unexplained variance; hence it is in the same units as the response variable. RMSE values spatially were esti- 


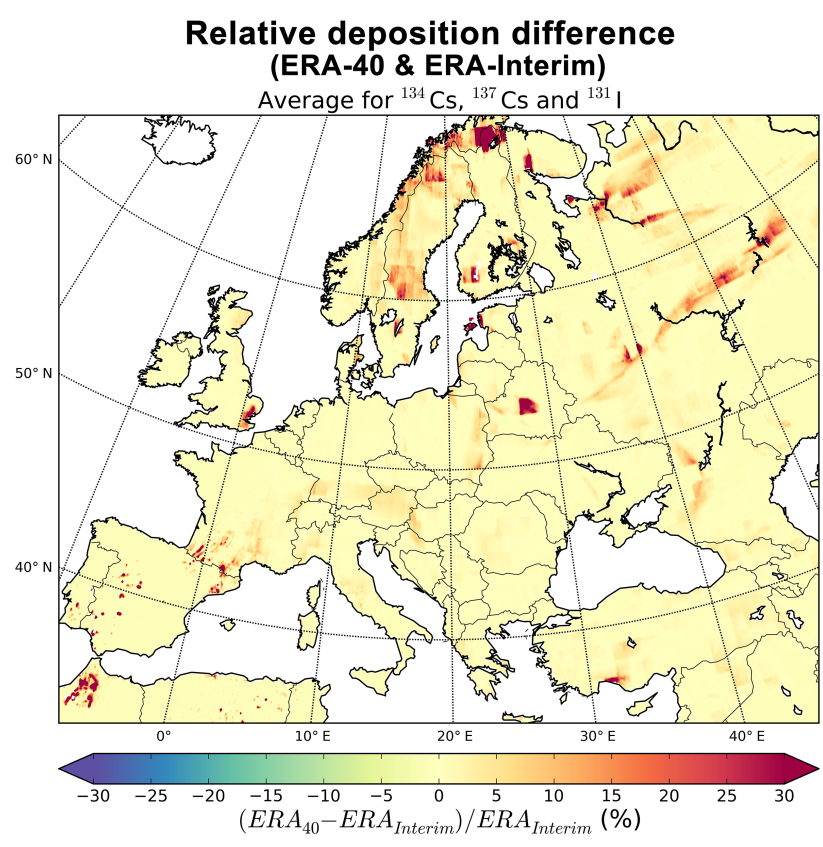

Figure 4. Percentage (\%) deposition difference between the ERA-40 and ERA-Interim data sets, i.e., (ERA $40^{-}$ $\mathrm{ERA}_{\text {Interim }}$ ) $/ \mathrm{ERA}_{\text {Interim in FLEXPART. The relative difference is }}$ an average for the radionuclides ${ }^{134} \mathrm{Cs},{ }^{137} \mathrm{Cs}$ and ${ }^{131} \mathrm{I}$.

mated for areas where deposition of radionuclides has shown large discrepancies from observations. The RMSE values averaged for all Scandinavian countries were estimated to be $47 \mathrm{kBq} \mathrm{m}^{-2}$ for ${ }^{134} \mathrm{Cs}$ and $36 \mathrm{kBq} \mathrm{m}^{-2}$ for ${ }^{137} \mathrm{Cs}$ using the ERA-Interim data set and only 36 and $27 \mathrm{kBq} \mathrm{m}^{-2}$ (for ${ }^{134} \mathrm{Cs}$ and ${ }^{137} \mathrm{Cs}$ ) using the ERA-40 fields. In Germany, RMSEs for ${ }^{134} \mathrm{Cs}$ and ${ }^{137} \mathrm{Cs}$ were 49 and $43 \mathrm{kBq} \mathrm{m}^{-2}$ using the ERAInterim and 41 and $32 \mathrm{kBq} \mathrm{m}^{-2}$ using the ERA-40 fields, whereas in Austria they decreased from 48 and $40 \mathrm{kBq} \mathrm{m}^{-2}$ to 44 and $35 \mathrm{kBq} \mathrm{m}^{-2}$, respectively. A different representation of deposition was also achieved for ${ }^{131} \mathrm{I}$, although there are not enough measurements to clearly decide which data set gave better results (Fig. 3).

According to Evangeliou et al. (2016), the total deposition of ${ }^{137} \mathrm{Cs}$ in Europe was $75 \mathrm{PBq}$, based on approximately 12000 measurements (shown also in Fig. 3) that were interpolated onto a regular grid. We calculated that $71 \mathrm{PBq}$ of ${ }^{137} \mathrm{Cs}$ were deposited over Europe using the prior release (Fig. 2) and ERA-40 fields. In contrast, deposition of ${ }^{137} \mathrm{Cs}$ using ERA-Interim was much lower (56 PBq). The same deposition pattern was found for ${ }^{131} \mathrm{I}$ and ${ }^{134} \mathrm{Cs}$, with deposited amounts to be $35 \%$ higher when using the ERA-40 reanalysis data set. The largest relative increase in deposition was estimated in Scandinavia, where models have struggled to reproduce deposition, in Belarus and in different parts of Russia. While it is somewhat surprising that ERA-40 allowed more realistic simulations than the more modern ERAInterim data set, we therefore selected the ERA-40 data as our reference data set for the inversion. The simulations performed with the ERA-Interim data set were used as ensemble members in the inversion to quantify the model uncertainties.

\subsection{Posterior emissions of ${ }^{134} \mathrm{Cs},{ }^{137} \mathrm{Cs}$ and ${ }^{131} \mathrm{I}$}

In this section, the results of the inversion using the prior source term shown in Figure 2 are discussed. According to our inversion, $80 \pm 5 \mathrm{PBq}$ of ${ }^{134} \mathrm{Cs}$ were released in total, with the highest emissions occurring on 26 and 28 April. Then the releases declined substantially but increased again on 3-5 May due to the fuel fire and the core meltdown (Fig. 5). This was consistent with what was previously reported for the accident (see Sect. 2 and references therein). We estimated that about $70 \mathrm{PBq}$ of ${ }^{134} \mathrm{Cs}$ were deposited all over Europe. Unfortunately, there exists no direct calculation of the total deposition of ${ }^{134} \mathrm{Cs}$ over Europe based on measurements due to the relatively short-lived nature of this radionuclide and thus lack of data. However, considering that the isotopic ratio ${ }^{134} \mathrm{Cs} /{ }^{137} \mathrm{Cs}$ for the Chernobyl accident was reported as 0.6 (Arvela et al., 1990) and about $75 \mathrm{PBq}$ of ${ }^{137} \mathrm{Cs}$ was deposited all over Europe according to measurements (Evangeliou et al., 2016), our ${ }^{134} \mathrm{Cs}$ source term might be a slight overestimate. With respect to the emission altitudes of ${ }^{134} \mathrm{Cs}$ averaged for the 12-day period, $37 \%$ was released below $0.5 \mathrm{~km}$ (against $71 \%$ in the prior), $5 \%$ at $0.5-1.0 \mathrm{~km}$ (against $4 \%$ ), $10 \%$ at $1.0-1.5 \mathrm{~km}$ (against $14 \%$ ), $16 \%$ at $1.5-2.0 \mathrm{~km}$ (against $9 \%$ ), $19 \%$ at $2.0-2.5 \mathrm{~km}$ (against $2 \%$ ) and $13 \%$ at $2.5-3.0 \mathrm{~km}$ (nothing was released above $2.5 \mathrm{~km}$ in the prior source term) (Table 1). Our optimized inversion lifted $47 \%$ of the releases above $1.5 \mathrm{~km}$, in contrast to only $11 \%$ in the prior source term.

Like the prior emissions, the posterior emissions of ${ }^{137} \mathrm{Cs}$ were high at the beginning of the accident due to the initial explosions, then decreased until they rose up again due to fuel meltdown (Fig. 5). Although our total posterior emissions are nearly the same as the prior emissions (86 against $74 \mathrm{PBq}$ ), posterior simulations resulted in less efficient deposition at close distances and more deposition over remote regions (see next section). The main difference in the source terms is a much higher release during the first day of the accident (29 PBq against $19 \mathrm{PBq}$ in the prior emissions). Furthermore, the releases on the first day occurred at much higher altitudes: $1.2 \mathrm{PBq}$ were released at altitudes up to $0.5 \mathrm{~km}$, $0.5 \mathrm{PBq}$ between 0.5 and $1.0 \mathrm{~km}, 10.3 \mathrm{PBq}$ between 1.0 and $1.5 \mathrm{~km}, 9 \mathrm{PBq}$ at $1.5-2.0 \mathrm{~km}, 5 \mathrm{PBq}$ at $2.0-2.5 \mathrm{~km}$ and $3 \mathrm{PBq}$ at $2.5-3.0 \mathrm{~km}$. The corresponding values in the prior source term were $0,0.3,9.5,7.5,2$ and $0 \mathrm{PBq}$. Thus, our inversion emits $28 \%$ of the releases of the first day above $2.0 \mathrm{~km}$ and $10 \%$ above $2.5 \mathrm{~km}$, in contrast to only 9 and $0 \%$ in the prior emissions, respectively. For the whole 12-day period, $21 \%$ of the posterior emissions were released above $2 \mathrm{~km}$, compared to only $2 \%$ of the prior emissions (see Table 1 ).

Finally, the posterior emissions of ${ }^{131}$ I were estimated as $1365 \mathrm{PBq}$ in total, about $10 \%$ lower than the prior total 
Table 1. Injection altitude (\% of total released mass) of prior and posterior emissions of ${ }^{134} \mathrm{Cs},{ }^{137} \mathrm{Cs}$ and ${ }^{131} \mathrm{I}$ averaged over the 12 -day period from 26 April 1986 until 7 May 1986.

\begin{tabular}{lrrrrrr}
\hline & $0-0.5 \mathrm{~km}$ & $0.5-1.0 \mathrm{~km}$ & $1.0-1.5 \mathrm{~km}$ & $1.5-2.0 \mathrm{~km}$ & $2.0-2.5 \mathrm{~km}$ & $2.5-3.0 \mathrm{~km}$ \\
\hline \multicolumn{2}{l}{ Prior releases } \\
\hline${ }^{134} \mathrm{Cs}$ & $71 \%$ & $4 \%$ & $14 \%$ & $9 \%$ & $2 \%$ & - \\
${ }^{137} \mathrm{Cs}$ & $70 \%$ & $4 \%$ & $14 \%$ & $10 \%$ & $2 \%$ & - \\
${ }^{131} \mathrm{I}$ & $68 \%$ & $8 \%$ & $10 \%$ & $9 \%$ & $5 \%$ & - \\
\hline \multicolumn{2}{l}{\begin{tabular}{l} 
Posterior releases \\
\multicolumn{1}{l}{${ }^{134} \mathrm{Cs}$}
\end{tabular}} & & & & & \\
${ }^{137} \mathrm{Cs}$ & $37 \%$ & $5 \%$ & $10 \%$ & $16 \%$ & $19 \%$ & $13 \%$ \\
${ }^{131} \mathrm{I}$ & $38 \%$ & $32 \%$ & $13 \%$ & $8 \%$ & $5 \%$ & $4 \%$ \\
\hline
\end{tabular}

releases. The temporal pattern of the posterior releases remained almost exactly as in the prior emissions (high emissions on 26 April, then a decrease followed by a slight increase towards the end of the 12-day period) (Fig. 5). The most notable difference was again related to the altitude of the injection. We estimate that $70 \%$ of the mass emitted was injected between below $1 \mathrm{~km}, 21 \%$ between 1 and $2 \mathrm{~km}$ and the rest $(9 \%)$ above $2 \mathrm{~km}$. The vertical profile of the prior releases was $76 \%$ at $0-1 \mathrm{~km}, 19 \%$ at $1-2 \mathrm{~km}$ and $5 \%$ at $2-$ $3 \mathrm{~km}$.

Overall, we found that the inversion shifted the emissions to higher altitudes compared with the prior estimates in order to better match observations. Specifically, $13 \%$ of the total emitted mass of ${ }^{134} \mathrm{Cs}, 10 \%$ of ${ }^{137} \mathrm{Cs}$ and $4 \%$ of ${ }^{131}$ I were injected above $2.5 \mathrm{~km}$, where no prior emissions occurred (Table 1). It seems likely that higher emission altitudes lead to reductions of the efficiency of dry and possibly also the wet deposition. As a consequence of this, increased atmospheric burdens, transport over longer distances and enhanced deposition in areas located far from the source can be expected. Another major change was that the inversion increased the emissions of ${ }^{134} \mathrm{Cs}$ and ${ }^{137} \mathrm{Cs}$ emissions on the first day by factors of 2.8 and 1.5 , respectively.

\subsection{Deposition over Europe using the optimized emissions}

The pronounced elevation of the posterior emissions of ${ }^{134} \mathrm{Cs}$ resulted in a higher deposition in remote areas compared to the simulation using prior emissions. More specifically, an indistinguishable increase of $5 \%$ was estimated in Scandinavia, mostly in Finland (north of Tampere) (Fig. 6). Another spatial increase in deposition was observed in the Alpine environments of Austria and Switzerland, where deposition was almost doubled (Fig. 6). Finally, in the FSU countries of Belarus and Russia deposition also increased by 20 and $64 \%$, respectively, whereas the same amount as in the simulation using the prior emissions was found in Ukraine but shifted slightly to the east (Fig. 6). Country-by-country comparison

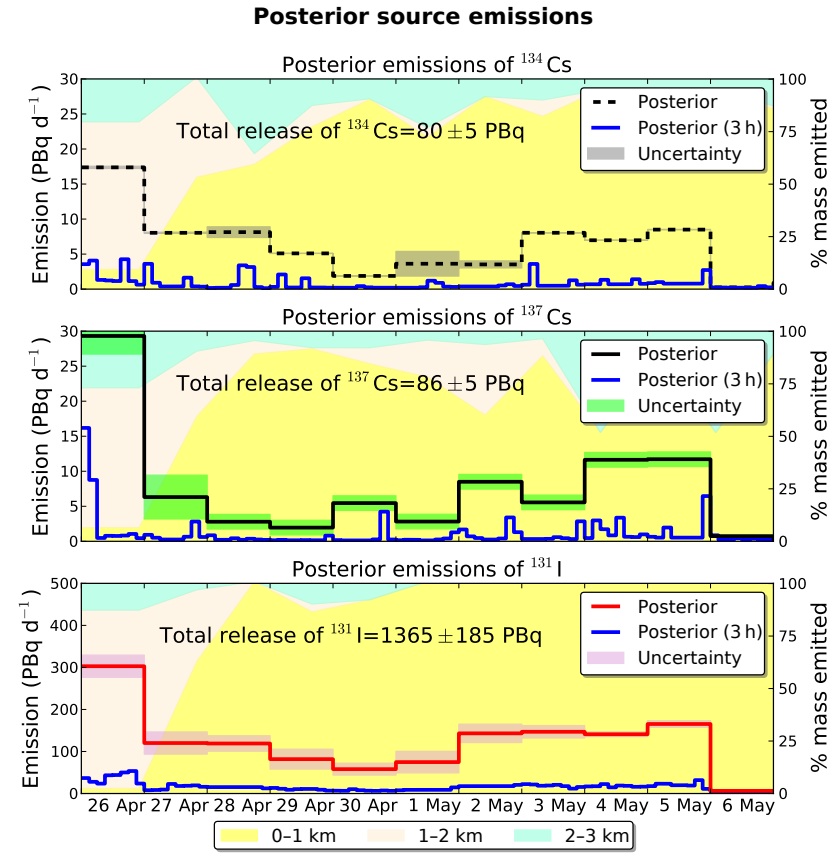

Figure 5. Daily posterior emissions of ${ }^{134} \mathrm{Cs},{ }^{137} \mathrm{Cs}$ and ${ }^{131} \mathrm{I}$ (red line) against uncertainty (sum of eight time steps per day) and 3 hourly posterior emissions (blue line) from 26 April to 7 May 1986. Note that emissions are plotted only until 6 May for simplicity, as they were close to zero during 7 May 1986. On the right axis the vertical distribution of the emissions at altitudes $0-1 \mathrm{~km}$ (yellow), $1-2 \mathrm{~km}$ (beige) and $2-3 \mathrm{~km}$ (turquoise) is plotted as shaded background colors.

of deposition of ${ }^{134} \mathrm{Cs}$ was not performed due to the lack of available measurements of ${ }^{134} \mathrm{Cs}$ over Europe.

The optimized emissions of ${ }^{137} \mathrm{Cs}$ resulted in a more accurate deposition over Europe compared to the published deposition maps (De Cort et al., 1998; Evangeliou et al., 2016) (Fig. 6). For instance, only trace amounts were deposited in the Baltic countries (Estonia, Latvia, Lithuania), using the optimized fluxes in contrast to the prior source 


\section{TOTAL DEPOSITION BEFORE \& AFTER THE INVERSION}
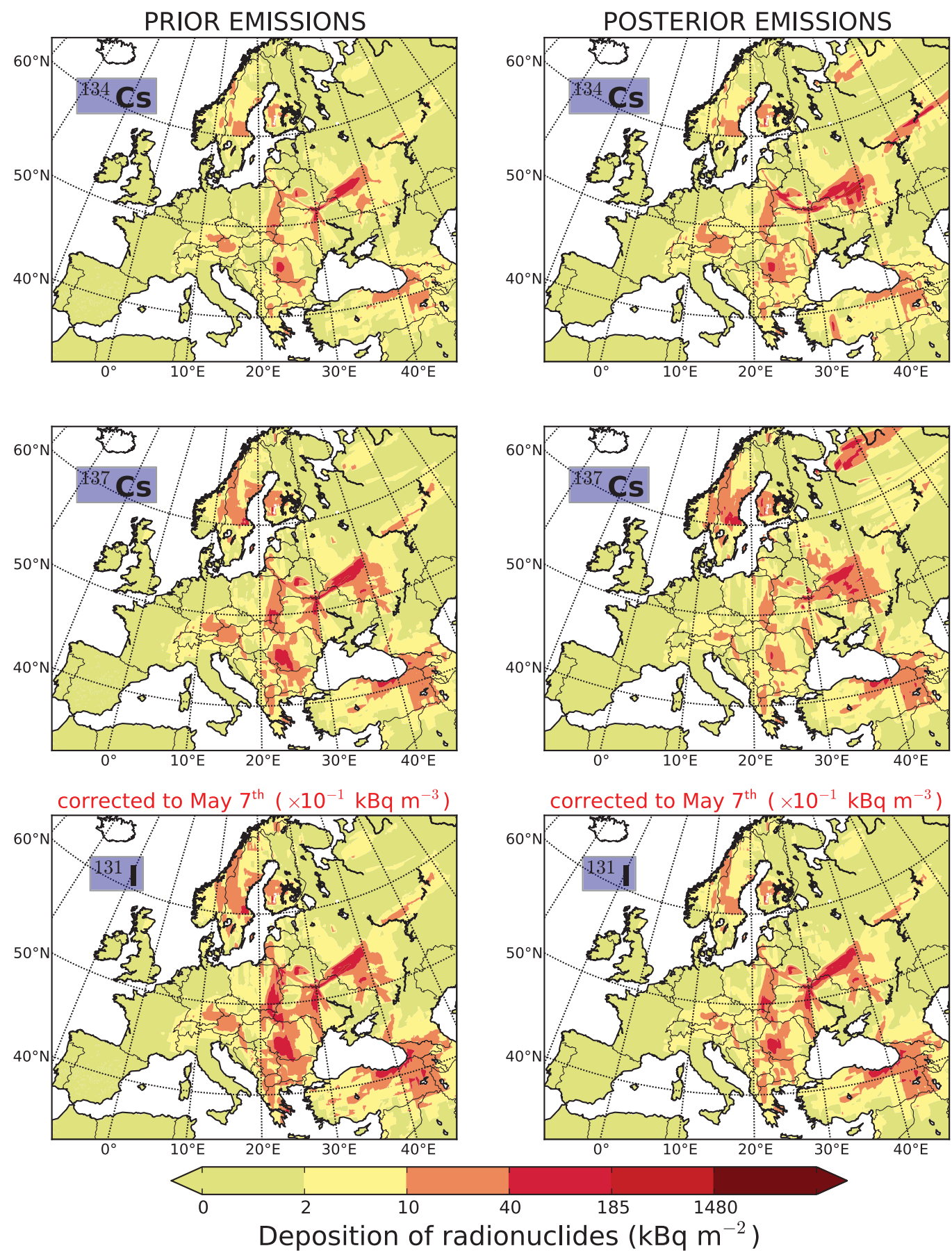

Figure 6. Cumulative deposition of ${ }^{134} \mathrm{Cs},{ }^{137} \mathrm{Cs}$ and ${ }^{131} \mathrm{I}$ using prior (left column) and posterior emissions (right column). Note that deposition of ${ }^{131}$ I was corrected for radioactive decay to the end date of the releases ( 7 May). Considering that emissions of ${ }^{131} \mathrm{I}$ were about 20 times higher than those of ${ }^{134} \mathrm{Cs}$ and ${ }^{137} \mathrm{Cs}$, total cumulative deposition of ${ }^{131} \mathrm{I}$ was scaled by a factor 0.1 in order to be able to use the same color scale as for the other radionuclides. 


\section{Validation using observations excluded from the inversion}
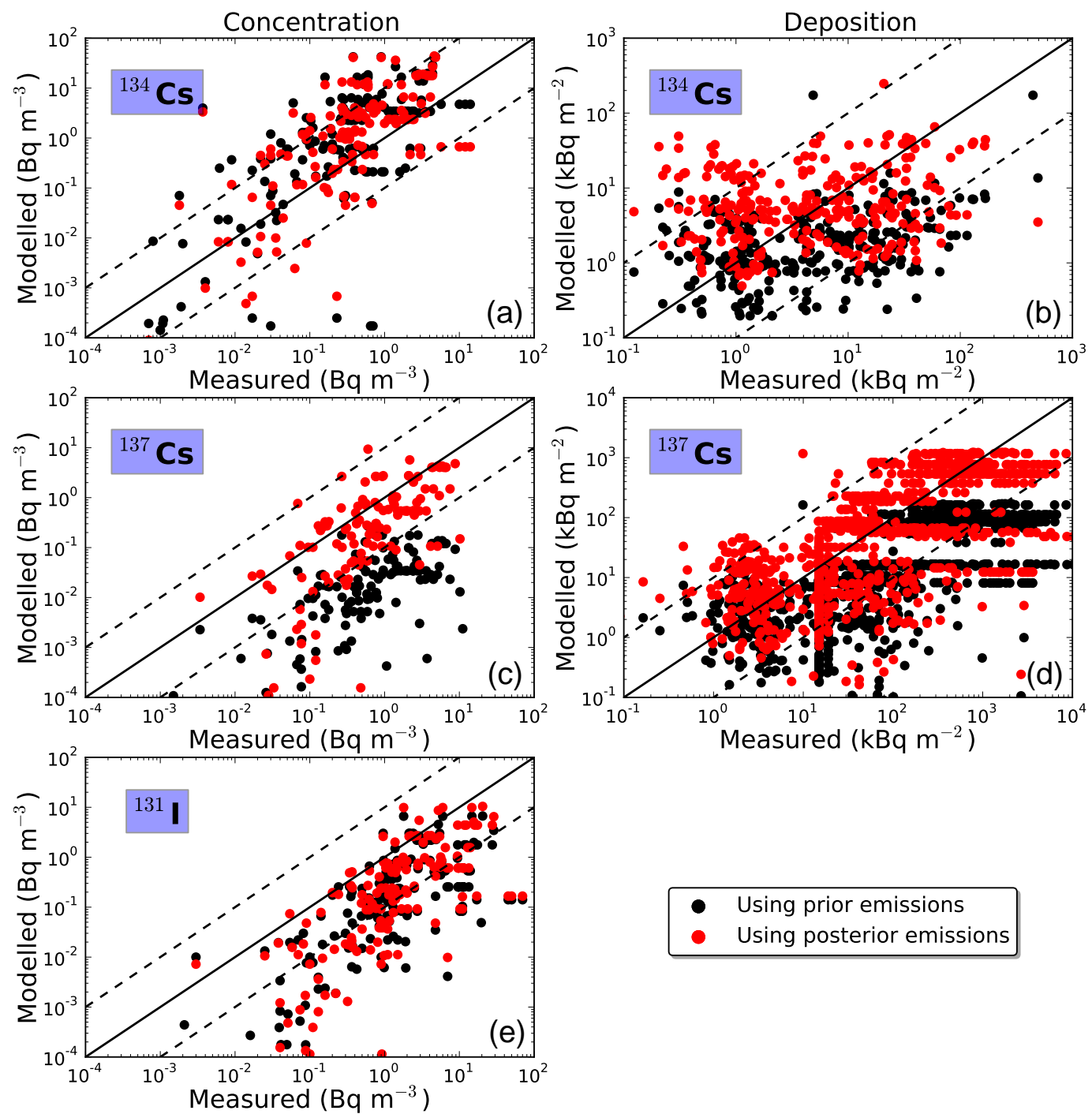

Figure 7. Left column: comparison of modeled concentrations with observations excluded from the inversions for ${ }^{134} \mathrm{Cs}\left(N_{134}=318\right)$, ${ }^{137} \mathrm{Cs}\left(N_{137}=232\right)$ and ${ }^{131} \mathrm{I}\left(N_{131}=318\right)$. Right column: comparison of modeled deposition densities with observations excluded from the inversions for ${ }^{134} \mathrm{Cs}\left(N_{134}=273\right)$ and ${ }^{137} \mathrm{Cs}\left(N_{137}=1115\right)$.

term. Decreased deposition compared to when using prior emissions was also observed in Eastern Europe (Poland, Romania, Czechia) or in the Balkan countries (Bulgaria, Former Yugoslavia, Greece), and it is also seen in the Atlas (De Cort et al., 1998). In contrast, about $30 \%$ higher deposition was observed in remote regions of Europe such as in Norway, Sweden and Finland, where measurements presented both in the Atlas and in Evangeliou et al. (2016) reveal ${ }^{137} \mathrm{Cs}$ values of more than $40 \mathrm{kBq} \mathrm{m}^{-2}$. This improvement by the presented posterior fluxes of ${ }^{137} \mathrm{Cs}$ mainly resulted in much higher deposited quantities in areas where to date most of the models have failed to reproduce the high observed deposition values (Brandt et al., 2002; Evangeliou et al., 2013;
Hass et al., 1990; Hatano et al., 1998). In addition, our results capture well the southeastern part of the Black Sea, where observations have not been included in the Atlas, but independent measurements have proven that deposition of ${ }^{137} \mathrm{Cs}$ there exceeded $40 \mathrm{kBq} \mathrm{m}^{-2}$ (Köse et al., 1994; Varinlioğlu et al., 1994). The latter is also captured well when using the prior releases. The only discord with our optimized fluxes is the existence of additional deposition in northwestern Russia, which is not seen in the Atlas. However, since groundbased measurements from this area are lacking, it remains unclear by which measurement data the Atlas results are actually supported. 


\section{Time series of atmospheric activity concentrations}

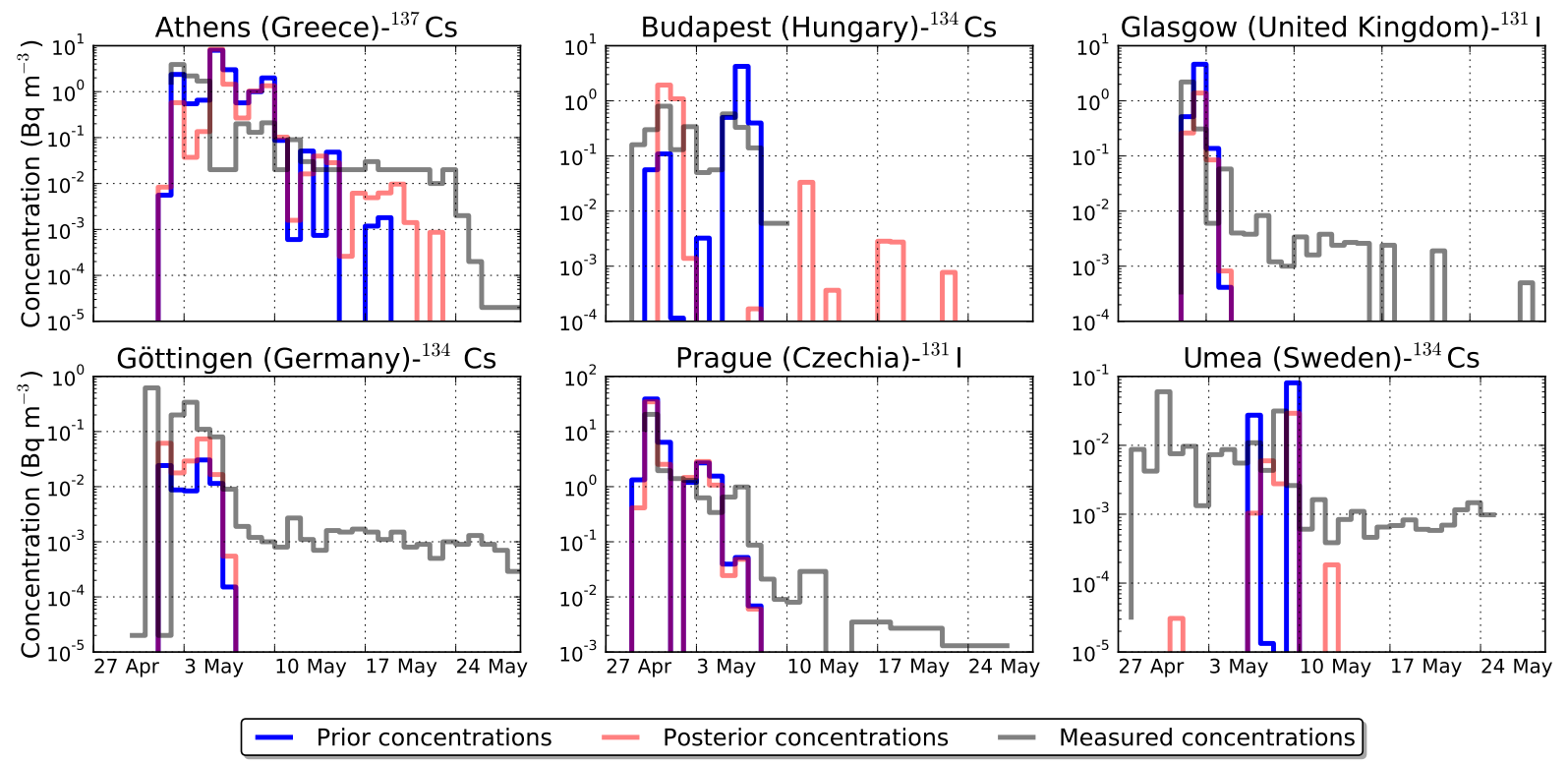

Figure 8. Time series of measured (grey) and simulated prior (blue) and posterior (red) concentrations of ${ }^{134} \mathrm{Cs}$, ${ }^{137} \mathrm{Cs}$ and ${ }^{131} \mathrm{I}$ for the stations Athens (Greece), Budapest (Hungary), Glasgow (UK), Göttingen (Germany), Prague (Czechia) and Umea (Sweden).

Due to the short-lived nature of ${ }^{131} \mathrm{I}$, few deposition measurements exist over Europe and it is not possible to compare our deposition maps with observations. However, despite the slightly lower posterior emissions (by $10 \%$ ), no difference in deposition patterns can be observed comparing to the prior emissions (Fig. 6). Nevertheless, absolute numbers show that deposition is slightly lower over Scandinavia, as well as in regions of Central Europe (e.g., Austria, southern Germany, Poland). The only way to validate these findings for ${ }^{131} \mathrm{I}$ is comparison with atmospheric activity concentrations reported by various groups in Europe (see next section).

\subsection{Validation of the inversion results against observations}

It was mentioned in Sect. 3.4 that a fraction of the measurements was excluded from the inversion. These data were used here for investigating the improvement obtained with the posterior source term compared to the prior source term. Comparison of simulated surface activity concentrations and deposition values of ${ }^{134} \mathrm{Cs},{ }^{137} \mathrm{Cs}$ and ${ }^{131} \mathrm{I}$ using the prior and the optimized (posterior) source terms are shown in Fig. 7. Furthermore, time series of activity concentrations that were excluded from the inversion (see Sect. 3.4) were compared with simulated concentrations obtained using the prior and posterior emissions (Fig. 8) for remote stations (Athens, Greece; Glasgow, UK; Umea, Sweden) and stations located closer to the Chernobyl NPP (Budapest, Hungary; Göttingen, Germany; Prague, Czechia).
The comparison of simulated and measured activity concentrations of ${ }^{134} \mathrm{Cs}$ using the prior and posterior fluxes showed generally low correlation coefficients $\left(R^{2} \leq 0.4\right)$ but small improvements when using posterior emissions $\left(R^{2}\right.$ increased from 0.2 to 0.4 ). Furthermore, the fraction of modeled values, which are within a factor of 10 from the measurements, increased from 63 to $75 \%$. This is also shown in the example time series for Budapest (Hungary), Göttingen (Germany) and Umea (Sweden), where the posterior concentration levels are closer to the observations in the beginning of the accident, but there was a drastic decrease afterwards (Fig. 8).

For the ${ }^{134} \mathrm{Cs}$ deposition data, the simulation using the posterior emissions increased the fraction of the data that are within a factor of 10 from the measurements $(65 \%$, compared to $58 \%$ using the prior emissions) (Fig. 7). RMSEs were improved in Scandinavia $\left(31 \mathrm{kBq} \mathrm{m}^{-2}\right.$ using the posterior releases compared to $36 \mathrm{kBq} \mathrm{m}^{-2}$ using the prior releases), as well as along the borders of Ukraine, Belarus and Russia, where a large portion was deposited. However, observations from these regions were included in the inversion and thus RMSEs cannot be estimated for independent measurements. The largest deviations close to the NPP were observed in the eastern part of Belarus (near Gomel), where measurements showed high deposition of radionuclides (see Atlas). However, deposition observations of ${ }^{134} \mathrm{Cs}$ from this particular area were limited (Fig. 3) and had a limited impact on the inversion.

For ${ }^{137} \mathrm{Cs}$ surface activity concentrations, there was a drastic improvement in agreement with independent data when 
FLEXPART with prior emissions

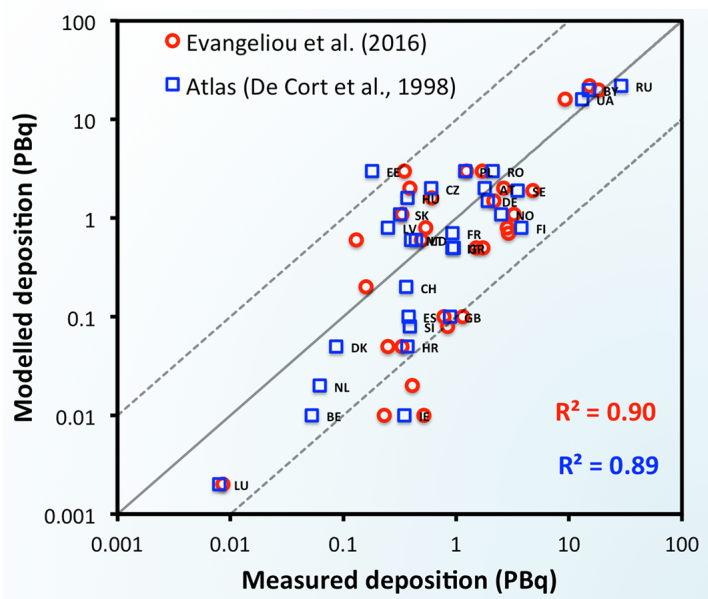

FLEXPART with posterior emissions

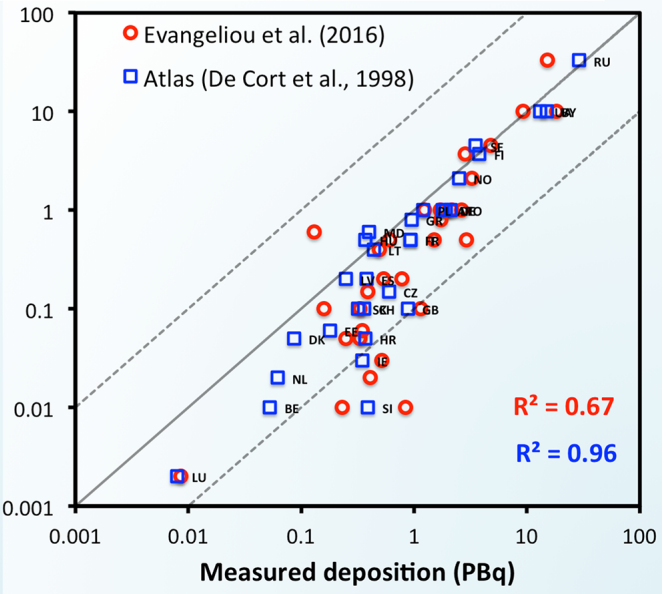

Figure 9. Country-by-country total cumulative deposition of ${ }^{137} \mathrm{Cs}$ simulated with FLEXPART model using the prior and posterior emissions vs. the estimated ones from the Atlas; De Cort et al., 1998) and from Evangeliou et al. (2016). The different countries are highlighted using their official country codes (Austria, AT; Belarus, BY; Belgium, BE; Croatia, HR; Czech Republic, CZ; Denmark, DK; Estonia, EE; Finland, FI; France, FR; Germany, DE; Greece, GR; Hungary, HU; Ireland, IE; Italy, IT; Latvia, LV; Lithuania, LT; Luxembourg, LU; Moldavia, MD; the Netherlands, NL; Norway, NO; Poland, PL; Rumania, RU; Russia, RU, European part; Slovak Republic, SK; Slovenia, SL; Spain, ES; Sweden, SE; Switzerland, CH; Ukraine, UA; and United Kingdom, GB).

using the posterior instead of the prior emissions (Fig. 7). The fraction of modeled data that were within a factor of 10 of the measured values increased from $18 \%$ using the prior emissions to $84 \%$ using the posterior emissions (Fig. 7). This is also apparent in the example of prior and posterior modeled and measured time series concentrations shown in Fig. 8 for Athens (Greece). Although the modeled concentrations were already in the right order of magnitude using the prior emissions, the inversion improved the agreement further, especially after 15 May. During this period, surface concentrations of ${ }^{137} \mathrm{Cs}$ using the prior releases were several orders of magnitude lower than in the observations (Fig. 8).

Similar to concentrations, deposition densities of ${ }^{137} \mathrm{Cs}$ using the posterior emissions showed better results than using the prior ones (Fig. 7). As for the concentrations, the posterior deposition values were generally increased, which is in better agreement with the observations. Specifically, the inversion increased the fraction of the modeled values that are within a factor 10 of the observations from only $54 \%$ using the prior emissions to $72 \%$, when the posterior source term was used. RMSEs decreased from 27 to $19 \mathrm{kBq} \mathrm{m}^{-2}$ in Scandinavia, from 32 to $29 \mathrm{kBq} \mathrm{m}^{-2}$ in Germany and from 35 to $27 \mathrm{kBq} \mathrm{m}^{-2}$ in Austria, confirming this better representation of deposition. However, near the NPP our results show poor agreement with the Atlas map estimating a generally lower deposition in Belarus and Ukraine and relatively higher deposition values in the Russian territory close to the borders with Ukraine and Belarus. This is probably the result of injecting posterior emissions at higher altitudes, which causes slower deposition of ${ }^{137} \mathrm{Cs}$ to nearby areas and enhances deposition over remote regions.
As the comparison of modeled grid-cell values with point observations is always problematic, we have also calculated the total modeled deposition in all European countries. We compare these values to the country totals from Evangeliou et al. (2016) and the Atlas (De Cort et al., 1998). Notice that for calculating the country totals, measurement data were used that were also ingested by the inversion. The results are shown in Fig. 9 for the simulations using the prior and the posterior emissions. Deposition of ${ }^{137} \mathrm{Cs}$ over Europe is already captured very well using the prior emissions with high correlation coefficients $\left(R^{2} \sim 0.9\right)$. However, it is obvious that, using the posterior fluxes, the deposition values of ${ }^{137} \mathrm{Cs}$ are closer to the identity line for both observation data sets, while high correlations are maintained (Fig. 9). High deposition in the countries of the FSU is also captured quite well, whereas deposition in Western Europe is slightly underestimated (e.g., in Belgium, Denmark, Ireland, Luxembourg and the Netherlands).

Finally, the releases of ${ }^{131} \mathrm{I}$ were estimated to be $1365 \pm 185 \mathrm{PBq}$, which is about $11 \%$ lower than in the prior emissions ( $1510 \pm 395 \mathrm{PBq})$. Comparing with independent observations, modeled ${ }^{131}$ I concentrations over Europe showed a slight improvement with $68 \%$ of the data within a factor of 10 from the observations in the posterior emissions, compared to $62 \%$ with the prior emissions. Unfortunately, observations of ${ }^{131}$ I deposition over Europe were unavailable due to the short half-life of ${ }^{131} \mathrm{I}$.

Another point worth highlighting is whether the model was able to correctly simulate the arrival times of the radioactive fallout. Figure 8 shows an example for the six different stations with independent data (Athens, Glasgow, Umea, Bu- 


\section{Depostion of Cesium-137 over Europe \& comparison with observations}
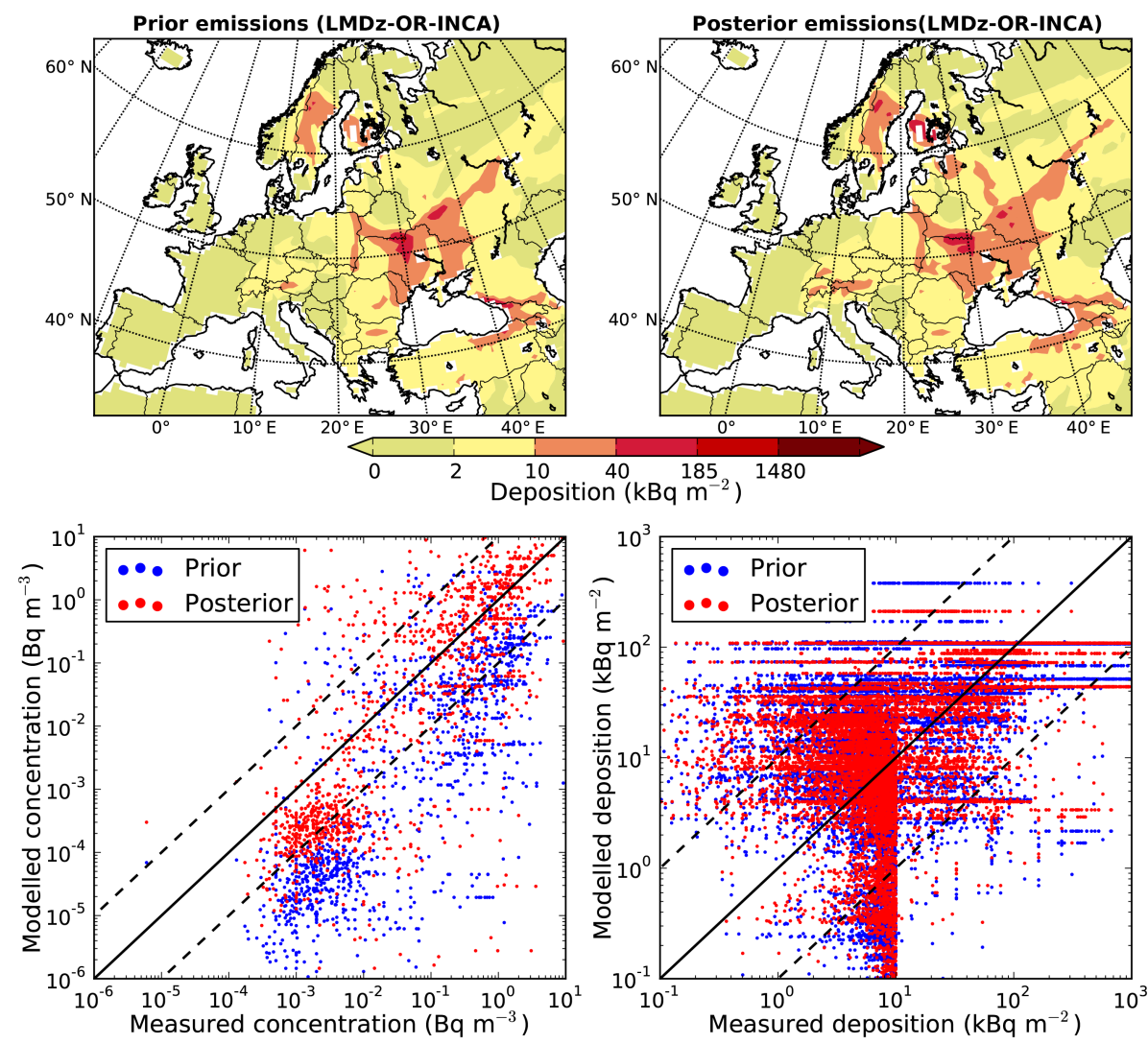

Figure 10. Deposition of ${ }^{137} \mathrm{Cs}$ using the Eulerian LMDz-OR-INCA chemistry transport model prior emissions from the ensemble of six a priori releases and the optimized emissions resulting from our inversion. Comparison of modeled surface concentrations and depositions of ${ }^{137} \mathrm{Cs}$ with observations from a recently published data set (Evangeliou et al., 2016).

dapest, Göttingen and Prague), for which the time series of concentrations have been plotted. It is obvious that the model was able to predict the arrival times to the measurement stations quite accurately. More specifically, it captured arrival times with a delay of up to 1 day, at maximum, in Southern Europe (Greece) and in Western (UK), Central (Germany) and Eastern Europe (Czechia and Hungary). In Northern Europe (Umea, Sweden), although the model captured the arrival time of the plume quite well, it failed to capture the right levels of the modeled concentrations that were several orders of magnitude lower.

Finally, the model did not reproduce well the duration of the plume passage, with typically a too-rapid concentration decrease after the peak concentrations were reached. This is probably attributed to potential remobilization of the deposited radionuclides and has been also confirmed both for Chernobyl (Garger et al., 1997, 1998; Nicholson, 1989; Rosner and Winkler, 2001) and Fukushima (Steinhauser et al., 2015; Stohl et al., 2012; Yamauchi, 2012). It has been found that after the first passage of the plume and the atmospheric removal of the transported radionuclides, radioactivity can be resuspended by the prevailing winds causing a secondary contamination. This is likely the reason that all three radionuclides were detected continuously in the measurements (Fig. 8) after the initial event, even when the air is not even coming from Chernobyl. The remobilization is also a problem for the inversion, which attempts to attribute the measured activity concentrations to direct releases from NPP. However, given that measured concentrations during such remobilization events are several orders of magnitude smaller than during the initial plume passage, this is not a severe problem.

\section{Discussion}

\subsection{Further validation of the posterior emissions using a Eulerian CTM}

We have used the LMDz-OR-INCA model to simulate the accident of Chernobyl independently of FLEXPART using 


\section{LMDz-OR-INCA with prior emissions}

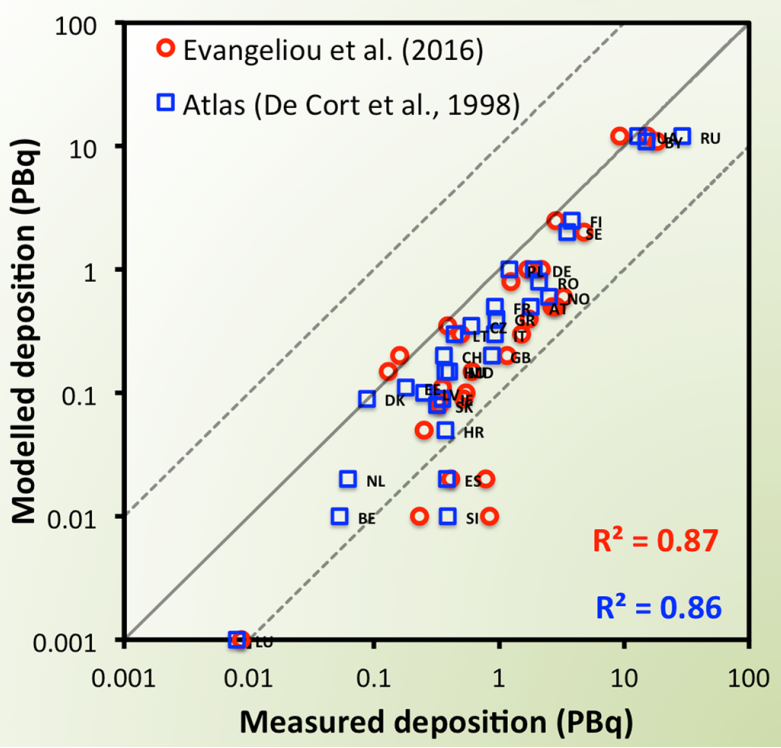

\section{LMDz-OR-INCA with superior emissions}

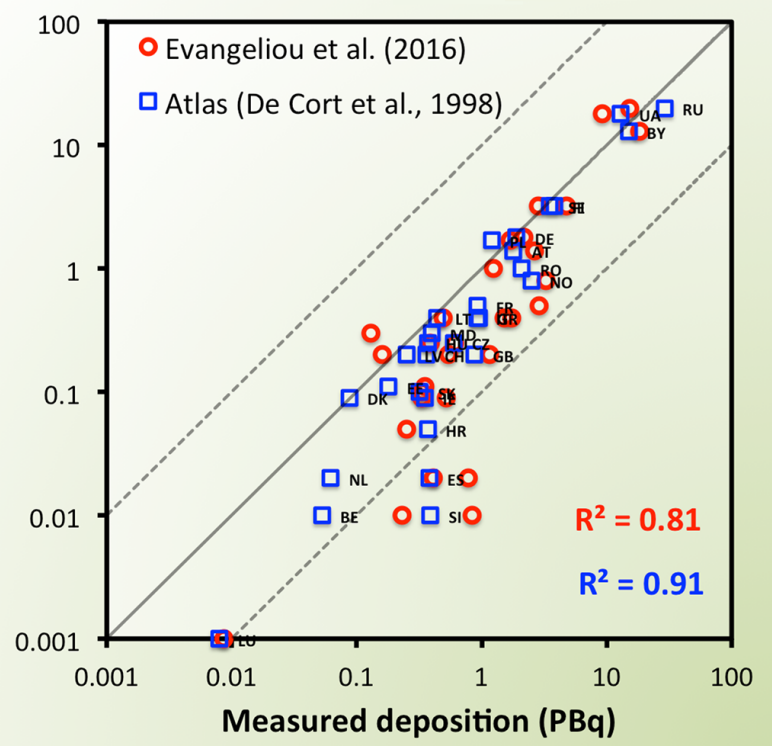

Figure 11. Country-by-country total cumulative simulated deposition of ${ }^{137} \mathrm{Cs}$ simulated with LMDz-OR-INCA model using the prior and the posterior emissions vs. the corresponding values estimated based on data from the Atlas (De Cort et al., 1998) and from Evangeliou et al. (2016). The different countries are named as in Fig. 9.

both the prior and posterior emissions (Fig. 10). The simulated surface activity concentrations and deposition densities of ${ }^{137} \mathrm{Cs}$ are compared with the most recently updated measurement data set (Evangeliou et al., 2016). Figure 10 shows that a much larger amount of ${ }^{137} \mathrm{Cs}$ was deposited over Europe using the obtained posterior emissions. In total numbers, $75 \mathrm{PBq}$ out of $86 \mathrm{PBq}$ (or $87 \%$ of the total released amount) was deposited over Europe using the optimized emissions and $63 \mathrm{PBq}$ out of $74 \mathrm{PBq}$ (or $85 \%$ of the total released amount) using the prior emissions. The posterior number agrees very well with the $77 \mathrm{PBq}$ total deposition of ${ }^{137} \mathrm{Cs}$ over Europe reported in the Atlas (De Cort et al., 1998). It is also consistent with the estimated total deposition of ${ }^{137} \mathrm{Cs}$ over Europe of $75 \mathrm{PBq}$ based on the measurement data set presented in Evangeliou et al. (2016). It is furthermore consistent with the deposited amount calculated using FLEXPART, approximately $80 \mathrm{PBq}$.

The improvement when using posterior emissions can also be seen in the direct comparison of simulated concentrations and deposition densities with measurements (Fig. 10, lower panel). It seems that the release of ${ }^{137} \mathrm{Cs}$ at higher altitudes in the posterior emissions resulted in much smaller wet and dry deposition in areas close to Chernobyl and more longrange transport of the radioactive fallout. This is translated into higher surface activity concentrations and deposition in remote regions of Europe. Accordingly, with the posterior emissions $85 \%$ of the modeled concentration values (in contrast to $47 \%$ using the prior emissions) are within a factor of 10 from measurements.
Comparison of simulated deposition with measurements did not show a large improvement using the prior and optimized emissions of ${ }^{137} \mathrm{Cs}$ despite the pronounced better representation of deposition over Europe. This is due to the fact that most of the measurements were collected close to the Chernobyl NPP and, therefore, hundreds of observations can be located within a single grid cell of LMDz-OR-INCA. Nevertheless, RMSEs decreased from 35 to $22 \mathrm{kBq} \mathrm{m}^{-2}$ in Scandinavia, from 48 to $45 \mathrm{kBq} \mathrm{m}^{-2}$ in Germany and from 45 to $31 \mathrm{kBq} \mathrm{m}^{-2}$ in Austria. To better assess the resulting deposition, we calculated again modeled country totals of ${ }^{137} \mathrm{Cs}$ deposition using both the prior and the posterior releases and compared them with the respective values from the Atlas and Evangeliou et al. (2016) (Fig. 11). In general, even with posterior emissions the model still underestimates deposition in countries that are not within the main direction of the fallout, such as Belgium, the Netherlands, Spain, France, Great Britain, Ireland and Italy. However, it manages to reproduce levels of contamination in Ukraine, Belarus and Russia, in Scandinavia (except for Norway that is still underestimated), in Central Europe (Poland, Germany and Austria), as well as around the Baltic countries. Almost all values were less than an order of magnitude lower than the observations maintaining high correlation coefficients for both data sets $\left(R^{2}>0.8\right)$.

\subsection{Uncertainty analysis}

While we propagate uncertainties in the inversion, it can be argued that true posterior uncertainties may be quite different 
Table 2. Sensitivity of posterior total emissions to (a) different prior emissions (six different previously published assessments), (b) using different injection altitudes in the prior source term, (c) replacing the ECMWF ERA-40 with the ERA-Interim meteorological data, (d) using only deposition data or (e) surface activity concentration measurements only and (f) using both deposition and concentration observations close to the NPP $\left(28-32^{\circ} \mathrm{E}, 48-52^{\circ} \mathrm{N}\right)$, expressed as relative differences to the reference inversion.

\begin{tabular}{lllllll}
\hline & $\begin{array}{l}\text { Different } \\
\text { prior emissions }\end{array}$ & $\begin{array}{l}\text { Different } \\
\text { injection profiles }\end{array}$ & $\begin{array}{l}\text { Different } \\
\text { meteorology }\end{array}$ & $\begin{array}{l}\text { Deposition } \\
\text { only }\end{array}$ & $\begin{array}{l}\text { Concentration } \\
\text { only }\end{array}$ & $\begin{array}{l}28-32^{\circ} \mathrm{E} \\
48-52^{\circ} \mathrm{N}\end{array}$ \\
\hline Posterior difference & $10 \%$ & $8.5 \%$ & $55 \%$ & $67 \%$ & $22 \%$ & $96 \%$ \\
\hline
\end{tabular}

from what we obtain. One reason is that even the prior uncertainties are not well characterized; another reason is that the inversion assumes that all data are independent and normally distributed. Furthermore, all measurements were taken about 31 years ago, from several different groups all over Europe that used various different techniques to determine radionuclide levels in soil or atmospheric aerosol; this induces an uncertainty that cannot be easily defined. Inversion uncertainty also depends on the uncertainty of the model, which is a function of the way it treats atmospheric transport and removal, both of which depend both on the meteorological input data as well as model parameterizations.

To better characterize the true uncertainty of our results and examine how robust our inversion is to different setups, we have performed numerous sensitivity tests. In each of them, we tuned different parameters of the inversion. More specifically, we have performed inversions (a) using six different prior source terms, (b) using three different injection profiles in the prior emissions, (c) using two different meteorological data sets (ECMWF ERA-40 and ERA-Interim), (d) including only deposition observations or (e) only activity concentrations and (f) including only observations (both concentrations and deposition densities) from areas close to the NPP $\left(28-32^{\circ} \mathrm{E}, 48-52^{\circ} \mathrm{N}\right)$. For each of the sensitivities, the standard deviations of the daily posterior emissions were calculated for the whole period, which are plotted as step function in Fig. S2 $\left(\mathrm{TBq} \mathrm{s}^{-1}\right)$. The results are averaged for the 12-day period in Table 2 for ${ }^{137} \mathrm{Cs}$ only, assuming that in relative terms they would be similar for ${ }^{134} \mathrm{Cs}$ and ${ }^{131} \mathrm{I}$, as - except for different decay corrections - they are treated in the same way within the model.

When six different prior source terms were used in the inversion (sensitivity test a), the total posterior emissions changed by only $10 \%$ (Table 2 ). This shows that the posterior emissions are robust against changes in prior emissions and the general pattern of high releases in the beginning and in the end of the 12-day period is well maintained in all six cases (Fig. S2). The largest differences in the posterior source term occurred for the first two time steps of 26 April and for the later days of the releases. The first is attributed to the large differences of the prior emissions during 26 April, which in some cases reached up to $70 \%$.

For the very first days of the accident the events that led to the releases of radionuclides are well known. Two explosions were witnessed immediately after the accident and the altitude of the injection was assessed pretty well. This is apparent from already published results from model simulations elsewhere (see Brandt et al., 2002; Evangeliou et al., 2013, and references therein). Small variations of the emission altitude (sensitivity test $b$ ) affect the inversion rather insignificantly, changing posterior emissions by only $8.5 \%$ (Table 2 ). Much larger differences, $55 \%$, were obtained when switching between different meteorological data sets (ERA-40 to ERA-Interim) (test c, Table 2). This is expected, as the precipitation fields in the ECMWF reanalysis are quite different from those in ERA-40, causing substantial differences in ${ }^{137}$ Cs deposition (see Fig. 4).

Other tests explored the sensitivity to using different subsets of measurements. For instance, when only concentration measurements were used in the inversion (test e) including a relative uncertainty in the measurements of $30 \%$ (see Sect. 3.4), emissions changed by only $22 \%$. When only deposition observations were used (associated with a relative uncertainty of $60 \%$, test d), posterior emissions were $67 \%$ higher than in our reference case. When the inversion was applied using the closest deposition and activity concentration observations $\left(28-32^{\circ} \mathrm{E}\right.$ and $48-52^{\circ} \mathrm{N}$, test $\left.\mathrm{f}\right)$, the obtained posterior emissions were doubled (Table 2). A likely reason for this deviation is the aerosol lifetime in FLEXPART (see Grythe et al., 2017). Of the emitted mass of each of the three radionuclides, $70 \%$ was in the sub-micronic and micronic mode. For particles in this range, dry deposition in FLEXPART is slow and also the below-cloud removal is not very efficient close to the source (Grythe et al., 2017). This probably led to an underestimate of deposition near the source, leading to emission increases when the higher observed deposition data are used. Lack of enough deposition was pronounced near the NPP (see Figure 6) and, hence, when using measurements from this small domain $\left(28-32^{\circ} \mathrm{E}\right.$ and 48 $52^{\circ} \mathrm{N}$ ) the inversion is forced towards higher releases.

\section{Conclusions}

We present a detailed inversion analysis of the most important radionuclides $\left({ }^{134} \mathrm{Cs},{ }^{137} \mathrm{Cs}\right.$ and $\left.{ }^{131} \mathrm{I}\right)$ released after the worst nuclear accident in human history, which occurred on 26 April 1986 in the FSU (nowadays, near the borders of Ukraine with Belarus and Russia). For the first time, in ad- 
dition to atmospheric activity concentration observations, we have also included deposition measurements adopted from a recently compiled data set to determine the Chernobyl source term. To constrain the inversion, we have used an ensemble of six different previously published source terms that include different injection altitudes, different total emitted mass and temporal variation of emissions in order to derive a prior source term and its associated uncertainty.

To drive the dispersion model, we used ECMWF reanalysis data. In tests we found that the model produced more realistic radionuclide deposition patterns with the ERA-40 reanalysis data set than with the ERA-Interim, especially in areas located far from the source (e.g., in Scandinavia, southeastern France and Scotland); thus ERA-40 was used as a reference for the inverse modeling. We calculated that $71 \mathrm{PBq}$ of ${ }^{137} \mathrm{Cs}$ were deposited over Europe using the prior release (Fig. 2) and ERA-40 fields, achieving $35 \%$ more deposition, at maximum, than using the ERA-Interim reanalysis data set.

Regarding the posterior emissions of ${ }^{134} \mathrm{Cs}$, about $80 \mathrm{PBq}$ were released in total with the same temporal pattern as in the prior source term, although these emissions are $32 \%$ higher than in Brandt et al. (2002), SCUAE (1986) and Waight et al. (1995) and $55 \%$ higher than those reported from Davoine and Bocquet (2007). From the released amount of ${ }^{134} \mathrm{Cs}$, about $70 \mathrm{PBq}$ was deposited all over Europe. Using as approximation for the deposited quantity, we estimated that these emissions might be slightly overestimated.

The posterior emissions of ${ }^{137} \mathrm{Cs}$ were high initially (due to the two explosions), then decreased and rose up again during the first days of May (due to the fuel meltdown). The total emissions of ${ }^{137} \mathrm{Cs}$ were estimated to be $86 \mathrm{PBq}$ (against $74 \mathrm{PBq}$ in the prior). Their magnitude is comparable to the emissions reported previously in Brandt et al. (2002), Izrael et al. (1990), Talerko (2005a) and Waight et al. (1995) and significantly lower than those reported by Davoine and Bocquet (2007) (136 PBq).

Finally, the posterior emissions of ${ }^{131} \mathrm{I}$ were estimated as $1365 \mathrm{PBq}$ or about $10 \%$ less than the prior total releases. This is $16 \%$ lower than the emissions reported in Brandt et al. (2002) and Davoine and Bocquet (2007) but almost 3 times higher than those reported in Izrael et al. (1990) and Persson et al. (1987) and about $35 \%$ higher than those in Talerko (2005b).

The most important conclusion for the optimized emissions of all three radionuclides included in this study is the characteristic tendency of the inversion to inject released amounts at higher altitudes. About $47 \%$ of the released ${ }^{134} \mathrm{Cs}$ was injected above $1.5 \mathrm{~km}$, in contrast to only $11 \%$ in the prior source term. For ${ }^{137} \mathrm{Cs}$, the portion that was injected above $1.5 \mathrm{~km}$ altitude was $26 \%$, relative to only $12 \%$ in the prior source term. The differences in prior and posterior emission profiles were smaller for ${ }^{131} \mathrm{I}(17 \%$ above $1.5 \mathrm{~km}$ in posterior emissions, $14 \%$ in prior ones), probably due to the limited amount of available observations over Europe.
The posterior emissions of ${ }^{137} \mathrm{Cs}$ were assessed independently using a Eulerian CTM (LMDz-OR-INCA) to simulate transport and deposition. We calculated that $87 \%$ (or $75 \mathrm{PBq}$ ) of ${ }^{137} \mathrm{Cs}$ posterior releases were deposited over Europe with LMDz-OR-INCA vs. $85 \%$ (63 PBq) using the prior releases of ${ }^{137} \mathrm{Cs}$ (in prior and posterior fluxes, the total released amount were 74 and $86 \mathrm{PBq}$, respectively). This deposited amount in Europe is similar to the reported one in the Atlas (77 PBq) and identical to the most recently published estimation that used different data but the same methodology as in the Atlas (75 PBq). The model tends to underestimate deposition in countries that are not in the main direction of the fallout, but it manages to reproduce contamination levels in most countries with correlation coefficients above 0.8 .

Overall, the results of our inversion for the radionuclides ${ }^{134} \mathrm{Cs},{ }^{137} \mathrm{Cs}$ and ${ }^{131} \mathrm{I}$ released after the Chernobyl accident were very robust against different setups of the inversion. From all sensitivity tests performed here, the maximum variation in the posterior emissions resulted when using measurements from a domain that includes only the highest deposition regions $\left(28-32^{\circ} \mathrm{E}\right.$ and $\left.48-52^{\circ} \mathrm{N}\right)$. The relatively inefficient modeled deposition near the NPP together with relatively high amounts of observed deposition increased the posterior emissions substantially. The source terms obtained in this study are available as a supplement to this paper.

Data availability. All data used for the present publication can be obtained from the corresponding author upon request.

\section{The Supplement related to this article is available online at https://doi.org/10.5194/acp-17-8805-2017-supplement.}

Author contributions. NE designed and performed the experiments and wrote the paper. $\mathrm{TH}$ designed the experiments and provided corrections on the inversion algorithm. YB wrote part of the paper. AC provided updates in the LMDz-OR-INCA model. AS designed and supervised the study and wrote parts of the paper.

Competing interests. The authors declare that they have no conflict of interest.

Acknowledgements. The present work was carried out in the frame of the STRADI project (Source Term Determination of Radionuclide Releases by Inverse Atmospheric Dispersion Modelling) of the Czech-Norwegian Research Programme (project ID: 7F14287). Computational and storage resources for the FLEXPART simulations have been provided by NOTUR (NN9419K) and NORSTORE (NS9419K). The development of inverse modeling tools was also supported by the Nordic Centre of Excellence eSTICC, funded by Nordforsk (number 57001). 
Edited by: Holger Tost

Reviewed by: two anonymous referees

\section{References}

Abagyan, A. A., Ilyin, L. A., Izrael, Y. A., Legasov, V. A., and Petrov, V. E.: The information on the Chernobyl accident and its consequences prepared for IAEA, Sov. At. Energy, 61, 301-320, https://doi.org/10.1007/BF01122262, 1986.

Albergel, A., Martin, D., Strauss, B., and Gros, J. M.: The chernobyl accident: Modelling of dispersion over europe of the radioactive plume and comparison with air activity measurements, Atmos. Environ., 22, 2431-2444, https://doi.org/10.1016/00046981(88)90475-1, 1988.

Andreev, I., Hittenberger, M., Hofer, P., Kromp-Kolb, H., Kromp, W., Seibert, P., and Wotawa, G.: Risks due to beyond design base accidents of nuclear power plants in Europe The methodology of riskmap, J. Hazard. Mater., 61, 257-262, https://doi.org/10.1016/S0304-3894(98)00130-7, 1998.

Aoyama, M., Hirose, K., and Sugimura, Y.: Deposition of gamma-emitting nuclides in Japan after the reactor-IV accident at Chernobyl, J. Radioan. Nucl. Ch. Ar., 116, 291-306, https://doi.org/10.1007/BF02035773, 1987.

Arvela, H., Markkanen, M., and Lemmela, H.: Mobile Survey of environmental gamma radiation and fallout level in Finland after Chernobyl accident, Radiat. Prot. Dosim., 32, 177-184, https://doi.org/10.1093/oxfordjournals.rpd.a080734, 1990.

Becker, A., Wotawa, G., Ringbom, A., and Saey, P. R. J.: Backtracking of noble gas measurements taken in the aftermath of the announced october 2006 event in North Korea by means of pts methods in nuclear source estimation and reconstruction, Pure Appl. Geophys., 167, 581-599, https://doi.org/10.1007/s00024009-0025-0, 2010.

Bondiett, E. A. and Brantley, J. N.: Characteristics of Chernobyl radioactivity in Tennessee, Nature, 322, 313-314, https://doi.org/10.1038/322313b0, 1986.

Brandt, J., Christensen, J. H., and Frohn, L. M.: Modelling transport and deposition of caesium and iodine from the Chernobyl accident using the DREAM model, Atmos. Chem. Phys., 2, 397-417, https://doi.org/10.5194/acp-2-397-2002, 2002.

Burakov, B. E., Strykanova, E. E., and Anderson, E. B.: Secondary Uranium Minerals on the Surface of Chernobyl "Lava", MRS Proceedings, 465, 1309-1311, https://doi.org/10.1557/PROC465-1309, 1996.

Cardis, E. L., Anspaugh, L., Ivanov, V. K., Likhtarev, I., Prisyazhniuk, A., Mabichi, K. and Okeanov, A. E.: Estimated long term health effects of the Chernobyl accident, in: International conference on one decade after Chernobyl: summing up the radiological consequences of the accident, Vienna, Austria, 8-12 April 1996, 241-279, available at: http://www.osti.gov/scitech/ servlets/purl/381695 (last access: 13 February 2017), 1996.

Chung, C. and Lo, J. G.: Radioactive I-131 over Taiwan after the Chernobyl accident, J. Radioanal. Nucl. Ch., 105, 325-333, https://doi.org/10.1007/BF02166343, 1986.

De Cort, M., Dubois, G., Fridman, S. D., Germenchuk, M., G., Izrael, Y. A., Janssens, A., Jones, A. R., Kelly, G., N., Kvasnikova, E., V., Matveenko, I., I., Nazarov, I., N., Pokumeiko, Y.,
M., Sitak, V. A., Stukin, E., D., Tabachny, L., Y., Tsaturov, Y. S. and Avdyushin, S. I.: Atlas of caesium deposition on Europe after the Chernobyl accident, EU - Office for Official Publications of the European Communities, Luxembourg, Catalogue number CG-NA-16-733-29-C, EUR 16733, 1-63, 1998.

Davoine, X. and Bocquet, M.: Inverse modelling-based reconstruction of the Chernobyl source term available for long-range transport, Atmos. Chem. Phys., 7, 1549-1564, https://doi.org/10.5194/acp-7-1549-2007, 2007.

Dee, D. P., Uppala, S. M., Simmons, A. J., Berrisford, P., Poli, P., Kobayashi, S., Andrae, U., Balmaseda, M. A., Balsamo, G., Bauer, P., Bechtold, P., Beljaars, A. C. M., van de Berg, L., Bidlot, J., Bormann, N., Delsol, C., Dragani, R., Fuentes, M., Geer, A. J., Haimberger, L., Healy, S. B., Hersbach, H., Hólm, E. V., Isaksen, L., Kållberg, P., Köhler, M., Matricardi, M., Mcnally, A. P., Monge-Sanz, B. M., Morcrette, J. J., Park, B. K., Peubey, C., de Rosnay, P., Tavolato, C., Thépaut, J. N., and Vitart, F.: The ERA-Interim reanalysis: Configuration and performance of the data assimilation system, Q. J. Roy. Meteorol. Soc., 137, 553597, https://doi.org/10.1002/qj.828, 2011.

Devell, L., Guntay, S., and Powers, D. A.: The Chernobyl reactor accident source term, Organisation for Economic Co-operation and Development, Nuclear Energy Agency, Paris, 1995.

Emanuel, K. A.: A Scheme for Representing Cumulus Convection in Large-Scale Models, J. Atmos. Sci., 48, 2313-2329, https://doi.org/10.1175/15200469(1991)048<:ASFRCC>.0.CO;2, 1991.

Evangeliou, N., Balkanski, Y., Cozic, A., and Møller, A. P.: Simulations of the transport and deposition of ${ }^{137} \mathrm{Cs}$ over Europe after the Chernobyl Nuclear Power Plant accident: influence of varying emission-altitude and model horizontal and vertical resolution, Atmos. Chem. Phys., 13, 7183-7198, https://doi.org/10.5194/acp-13-7183-2013, 2013.

Evangeliou, N., Hamburger, T., Talerko, N., Zibtsev, S., Bondar, Y., Stohl, A., Balkanski, Y., Mousseau, T. A., and Møller, A. P.: Reconstructing the Chernobyl Nuclear Power Plant (CNPP) accident 30 years after. A unique database of air concentration and deposition measurements over Europe, Environ. Pollut., 216, 408-418, https://doi.org/10.1016/j.envpol.2016.05.030, 2016.

Fairlie, I. and Sumner, D.: The other report on Chernobyl (TORCH), commissioned by Rebecca Harms, MEP, Greens/EFA in the European Parliament with the support of The Altner Combecher Foundation, Berlin, Brussels, Kiev, available at: http://www. chernobylreport.org/torch.pdf, 2006.

Folberth, G. A., Hauglustaine, D. A., Lathière, J., and Brocheton, F.: Interactive chemistry in the Laboratoire de Météorologie Dynamique general circulation model: model description and impact analysis of biogenic hydrocarbons on tropospheric chemistry, Atmos. Chem. Phys., 6, 2273-2319, https://doi.org/10.5194/acp-6-2273-2006, 2006.

Forster, C., Stohl, A., and Seibert, P.: Parameterization of convective transport in a Lagrangian particle dispersion model and its evaluation, J. Appl. Meteorol. Clim., 46, 403-422, https://doi.org/10.1175/JAM2470.1, 2007.

Garger, E. K., Hoffman, F. O., and Thiessen, K. M.: Uncertainty of the long-term resuspension factor, Atmos. Environ., 31, 16471656, https://doi.org/10.1016/S1352-2310(96)00345-7, 1997.

Garger, E. K., Kashpur, V., Paretzke, H. G., and Tschiersch, J.: Measurement of resuspended aerosol in the Chernobyl area: Part II. 
Size distribution of radioactive particles, Radiat. Environ. Bioph., 36, 275-283, https://doi.org/10.1007/s004110050082, 1998.

Grythe, H., Kristiansen, N. I., Groot Zwaaftink, C. D., Eckhardt, S., Ström, J., Tunved, P., Krejci, R., and Stohl, A.: A new aerosol wet removal scheme for the Lagrangian particle model FLEXPART v10, Geosci. Model Dev., 10, 1447-1466, https://doi.org/10.5194/gmd-10-1447-2017, 2017.

Gudiksen, H. P., Harvey, T. F., and Lange, R.: Chernobyl source term, atmospheric dispersion, and dose estimation, Health Phys., 57, 697-706, https://doi.org/10.1097/00004032198911000-00001, 1989.

Hamilton, E. I., Zou, B., and Clifton, R. J.: The Chernobyl accident - Radionuclide fallout in S.W.England, Sci. Total Environ., 57, 231-251, 1986.

Hass, H., Memmesheimer, M., Geiß, H., Jakobs, H. J., Laube, M., and Ebel, A.: Simulation of the chernobyl radioactive cloud over Europe using the eurad model, Atmos. Environ. A Gen., 24, 673692, https://doi.org/10.1016/0960-1686(90)90022-F, 1990.

Hatano, Y., Hatano, N., Amano, H., Ueno, T., Sukhoruchkin, A. K., and Kazakov, S. V.: Aerosol migration near Chernobyl: Long-term data and modeling, Atmos. Environ., 32, 2587-2594, https://doi.org/10.1016/S1352-2310(97)00511-6, 1998.

Hauglustaine, D. A., Hourdin, F., Jourdain, L., Filiberti, M.A., Walters, S., Lamarque, J.-F., and Holland, E. A.: Interactive chemistry in the Laboratoire de Meteorologie Dynamique general circulation model: Description and background tropospheric chemistry evaluation, J. Geophys. Res., 109, D04314, https://doi.org/10.1029/2003JD003957, 2004.

Hourdin, F. and Armengaud, A.: The Use of Finite-Volume Methods for Atmospheric Advection of Trace Species. Part I: Test of Various Formulations in a General Circulation Model, Mon. Weather Rev., 127, 822-837, https://doi.org/10.1175/15200493(1999)127<:TUOFVM>.0.CO;2, 1999.

Hourdin, F. and Issartel, J. P.: Sub-surface nuclear tests monitoring through the CTBT xenon network, Geophys. Res. Lett., 27, 2245-2248, https://doi.org/10.1029/1999GL010909, 2000.

Hourdin, F., Musat, I., Bony, S., Braconnot, P., Codron, F., Dufresne, J. L., Fairhead, L., Filiberti, M. A., Friedlingstein, P., Grandpeix, J. Y., Krinner, G., LeVan, P., Li, Z. X., and Lott, F.: The LMDZ4 general circulation model: Climate performance and sensitivity to parametrized physics with emphasis on tropical convection, Clim. Dynam., 27, 787-813, https://doi.org/10.1007/s00382-006-0158-0, 2006.

IAEA: The Chernobyl accident: Updating of INSAG-1. A report by the International Nuclear Safety Advisory Group, Safety Series No. 75-INSAG-7, International Atomic Energy Agency (IAEA), Vienna, available at: http://www-pub.iaea.org/MTCD/ publications/PDF/Pub913eweb.pdf (last access: 14 February 2017), 1992.

Izrael, Y. A., Vakulovsky, S. M., Vetrov, V. A., Petrov, V. N., Rovinsky, F. Y., and Stukin, E. D.: Chernobyl: Radioactive Contamination of the Environment, Gidrometeoizdat, 1990.

Izrael, Y. A., De Cort, M., Jones, A. R., Nazarov, I. M., Fridman, S. D., Kvasnikova, E. V., Stukin, E. D., Kelly, G. N., Matveenko, I. I., Pokumeiko, Y. M., Tabatchnyi, L. Y., and Tsaturon, Y.: The atlas of caesium-137 contamination of Europe after the Chernobyl accident, in: The radiological consequences of the Chernobyl accident, edited by: Karaoglou, A., Desmet, G., Kelly, G. N., and
Menzel, H. G., European Commission, EUR 16544 EN, 1-10, 1996.

JRC: Radioactivity Environmental Monitoring (REM), EU Joint Research Centre, available at: https://rem.jrc.ec.europa.eu/ RemWeb/Index.aspx\#, last access: 22 November 2016.

Kashparov, V. A., Lundin, S. M., Zvarych, S. I., Yoshchenko, V. I., Levchuk, S. E., Khomutinin, Y. V., Maloshtan, I. M., and Protsak, V. P.: Territory contamination with the radionuclides representing the fuel component of Chernobyl fallout, Sci. Total Environ., 317, 105-119, https://doi.org/10.1016/S0048-9697(03)00336-X, 2003.

Kauppinen, E. I., Hillamo, R. E., Aaltonen, S. H., and Sinkko, K. T. S.: Radioactivity size distributions of ambient aerosols in Helsinki, Finland, during May 1986 after Chernobyl accident: preliminary report, Environ. Sci. Technol., 20, 1257-1259, https://doi.org/10.1021/es00154a011, 1986.

Köse, A., Topcuoğlu, S., Varinlioğlu, A., Kopya, A. I., Azar, A., Uzun, O., and Karal, H.: The levels of cesium radionuclides in lichens in the eastern black sea area of turkey, Toxicol. Environ. Chem., 45, 221-224, https://doi.org/10.1080/02772249409358087, 1994.

Krinner, G., Viovy, N., de Noblet-Ducoudré, N., Ogée, J., Polcher, J., Friedlingstein, P., Ciais, P., Sitch, S., and Prentice, I. C.: A dynamic global vegetation model for studies of the coupled atmosphere-biosphere system, Global Biogeochem. Cy., 19, GB1015, https://doi.org/10.1029/2003GB002199, 2005.

Kristiansen, N. I., Stohl, A., Prata, A. J., Richter, A., Eckhardt, S., Seibert, P., Hoffmann, A., Ritter, C., Bitar, L., Duck, T. J., and Stebel, K.: Remote sensing and inverse transport modeling of the Kasatochi eruption sulfur dioxide cloud, J. Geophys. Res., 115, D00L16, https://doi.org/10.1029/2009JD013286, 2010.

Lange, R., Dickerson, M. H., and Gudiksen, P. H.: Dose Estimates from the Chernobyl Accident, Nucl. Technol., 82, 311323, 1988.

Malá, H., Rulík, P., Bečková, V., Mihalík, J., and Slezáková, M.: Particle size distribution of radioactive aerosols after the Fukushima and the Chernobyl accidents, J. Environ. Radioactiv., 126, 92-98, https://doi.org/10.1016/j.jenvrad.2013.07.016, 2013.

Medvedev, Z. A.: The legacy of Chernobyl, W.W. Norton, New York, available at: https://search.library.wisc.edu/catalog/ 999619878702121 (last access: 14 February 2017), 1990.

Nicholson, K. W.: The deposition , resuspension and weathering of Chernobyl derived material in the UK, Nature, 9, 113-119, https://doi.org/10.1088/0952-4746/9/2/004, 1989.

Nishizaw, K., Takata, K., Hamada, N., Ogata, Y., Kojima, S., Yamashit, O., Ohshima, M., and Kayama, Y.: I-131 in milk and rain Chernobyl, Nature, 342, 308, https://doi.org/10.1038/324308a0, 1986.

Persson, C., Rodhe, H., and De Geer, L.-E.: The Chernobyl accident - A meteorological analysis of how radionuclides reached and were deposited in Sweden, Ambio, 16, 20-31, 1987.

Rosner, G. and Winkler, R.: Long-term variation (1986-1998) of post-Chernobyl $90 \mathrm{Sr}, 137 \mathrm{Cs}, 238 \mathrm{Pu}$ and $(239,240) \mathrm{Pu}$ concentrations in air, depositions to ground, resuspension factors and resuspension rates in south Germany, Sci. Total Environ., 273, , 11-25, https://doi.org/10.1016/S0048-9697(00)00716-6, 2001.

Saiz-Lopez, A., Plane, J. M. C., Baker, A. R., Carpenter, L. J., von Glasow, R., Gómez Martín, J. C., McFiggans, G., and Saun- 
ders, R. W.: Atmospheric Chemistry of Iodine, Chem. Rev., 112, 1773-1804, https://doi.org/10.1021/cr200029u, 2012.

Schulz, M.: Constraining model estimates of the aerosol Radiative Forcing, Université Pierre et Marie Curie, Paris VI, 2007.

SCUAE: The accident at the Chernobyl Nuclear Power Plant and its consequences, USSR State Committee on The Utilization of Atomic Energy, Parts I and II, Information compiled for the IAEA experts' Meeting, Vienna, 25-29 August 1986.

Seibert, P.: Inverse modelling of sulfur emissions in Europe based on trajectories, in: Inverse Methods in Global Biogeochemical Cycles, edited by: Kasibhatla, P., Heimann, M., Rayner, P., Mahowald, N., Prinn, R. G., and Hartley, D. E., American Geophysical Union, Washington, DC, Geophysical Monograph, 114, 147154, 2000.

Seibert, P., Kristiansen, N. I., Richter, A., Eckhardt, S., Prata, A. J., and Stohl, A.: Uncertainties in the inverse modelling of sulphur dioxide eruption profiles, Geomatics, Nat. Hazards Risk, 2, 201216, https://doi.org/10.1080/19475705.2011.590533, 2011.

Simondi-Teisseire, B., Girault, N., Payot, F., and Clément, B.: Iodine behaviour in the containment in Phébus FP tests, Ann. Nucl. Energy, 61, 157-169, https://doi.org/10.1016/j.anucene.2013.02.039, 2013.

Steinhauser, G., Niisoe, T., Harada, K. H., Shozugawa, K., Schneider, S., Synal, H. A., Walther, C., Christl, M., Nanba, K., Ishikawa, H., and Koizumi, A.: Post-Accident Sporadic Releases of Airborne Radionuclides from the Fukushima Daiichi Nuclear Power Plant Site, Environ. Sci. Technol., 49, 14028-14035, https://doi.org/10.1021/acs.est.5b03155, 2015.

Stohl, A., Hittenberger, M., and Wotawa, G.: Validation of the lagrangian particle dispersion model FLEXPART against largescale tracer experiment data, Atmos. Environ., 32, 4245-4264, https://doi.org/10.1016/S1352-2310(98)00184-8, 1998.

Stohl, A., Forster, C., Frank, A., Seibert, P., and Wotawa, G.: Technical note: The Lagrangian particle dispersion model FLEXPART version 6.2, Atmos. Chem. Phys., 5, 2461-2474, https://doi.org/10.5194/acp-5-2461-2005, 2005.

Stohl, A., Seibert, P., Arduini, J., Eckhardt, S., Fraser, P., Greally, B. R., Lunder, C., Maione, M., Mühle, J., O’Doherty, S., Prinn, R. G., Reimann, S., Saito, T., Schmidbauer, N., Simmonds, P. G., Vollmer, M. K., Weiss, R. F., and Yokouchi, Y.: An analytical inversion method for determining regional and global emissions of greenhouse gases: Sensitivity studies and application to halocarbons, Atmos. Chem. Phys., 9, 1597-1620, https://doi.org/10.5194/acp-9-1597-2009, 2009.

Stohl, A., Prata, A. J., Eckhardt, S., Clarisse, L., Durant, A., Henne, S., Kristiansen, N. I., Minikin, A., Schumann, U., Seibert, P., Stebel, K., Thomas, H. E., Thorsteinsson, T., Tørseth, K., and Weinzierl, B.: Determination of time- and height-resolved volcanic ash emissions and their use for quantitative ash dispersion modeling: the 2010 Eyjafjallajökull eruption, Atmos. Chem. Phys., 11, 4333-4351, https://doi.org/10.5194/acp-114333-2011, 2011.

Stohl, A., Seibert, P., Wotawa, G., Arnold, D., Burkhart, J. F., Eckhardt, S., Tapia, C., Vargas, A., and Yasunari, T. J.: Xenon133 and caesium-137 releases into the atmosphere from the Fukushima Dai-ichi nuclear power plant: determination of the source term, atmospheric dispersion, and deposition, Atmos. Chem. Phys., 12, 2313-2343, https://doi.org/10.5194/acp-122313-2012, 2012.
Talerko, N.: Mesoscale modelling of radioactive contamination formation in Ukraine caused by the Chernobyl accident, J. Environ. Radioactiv., 78, 311-329, https://doi.org/10.1016/j.jenvrad.2004.04.008, 2005a.

Talerko, N.: Reconstruction of ${ }^{131}$ I radioactive contamination in Ukraine caused by the Chernobyl accident using atmospheric transport modelling, J. Environ. Radioactiv., 84, 343362, https://doi.org/10.1016/j.jenvrad.2005.04.005, 2005b.

Tsaturov, Y. S., De Cort, M., Dubois, G., Tabachnyi, L. Y., Matveenko, I. I., and Guermenchuk, M. G.: The Need for Standardisation in the Analysis, Sampling and Measurement of deposited Radionuclides, edited by: Karaoglou, A., Desmet, G., Kelly, G. N., and Menzel, H. G., European Commission, Brussels, 425-433, available at: http://www.iaea.org/inis/collection/ NCLCollectionStore/_Public/31/056/31056873.pdf (last access: 20 February 2017), 1996.

Uppala, S. M., Kallberg, P. W., Simmons, A. J., Andrae, U., Bechtold, V. D., Fiorino, M., Gibson, J. K., Haseler, J., Hernandez, A., Kelly, G. A., Li, X., Onogi, K., Saarinen, S., Sokka, N., Allan, R. P., Andersson, E., Arpe, K., Balmaseda, M. A., Beljaars, A. C. M., Van De Berg, L., Bidlot, J., Bormann, N., Caires, S., Chevallier, F., Dethof, A., Dragosavac, M., Fisher, M., Fuentes, M., Hagemann, S., Holm, E., Hoskins, B. J., Isaksen, L., Janssen, P. A. E. M., Jenne, R., McNally, A. P., Mahfouf, J. F., Morcrette, J. J., Rayner, N. A., Saunders, R. W., Simon, P., Sterl, A., Trenberth, K. E., Untch, A., Vasiljevic, D., Viterbo, P., and Woollen, J.: The ERA-40 re-analysis, Q. J. Roy. Meteorol. Soc., 131, 2961-3012, https://doi.org/10.1256/qj.04.176, 2005.

Varinlioğlu, A., Topcuoğlu, S., Köse, A., Kopya, A. I., Uzun, O., Azar, A., and Karal, H.: Levels of cesium radionuclides in mosses in the eastern Black Sea area of Turkey, J. Radioanal. Nucl. Ch., 187, 435-440, https://doi.org/10.1007/BF02165773, 1994.

Waight, P., Metivier, H., Jacob, P., Soulchkevitch, G., Viktorsson, C., Bennett, B., Hance, R., Yumazawa, S., Kusumi, S., Bouville, A., Sinnaeve, J., Ilari, O., and Lazo, E.: Chernobyl - Ten Years on: Radiological and Health Impact, OECD Nuclear Energy Agency and OECD Nuclear Energy Agency, Committee on Radiation Protection and Public Health, 1995.

Wotawa, G., Becker, A., Kalinowski, M., Saey, P., Tuma, M., and Zähringer, M.: Computation and analysis of the global distribution of the radioxenon isotope ${ }^{133} \mathrm{Xe}$ based on emissions from nuclear power plants and radioisotope production facilities and its relevance for the verification of the nuclear-test-ban treaty, Pure Appl. Geophys., 167, 541-557, https://doi.org/10.1007/s00024-009-0033-0, 2010.

Yamauchi, M.: Secondary wind transport of radioactive materials after the Fukushima accident, Earth Planets Space, 64, e1-e4, https://doi.org/10.5047/eps.2012.01.002, 2012. 